\title{
Ecology and Fish Biodiversity of Man-Made Lakes of Southern Benin (West Africa): Implications for Species Conservation and Fisheries Management
}

\author{
Houehanou M. A. G. Gbaguidi1, Alphonse Adite ${ }^{1 *}$, Edmond Sossoukpe ${ }^{2}$ \\ ${ }^{1}$ Laboratoire d'Ecologie et de Management des Ecosystèmes Aquatiques (LEMEA), Département de Zoologie, \\ Faculté des Sciences et Techniques, Université d'Abomey-Calavi, Cotonou, Bénin \\ ${ }^{2}$ Unité de Recherches sur les Zones Humides, Département de Zoologie, Faculté des Sciences et Techniques, \\ Université d'Abomey-Calavi, Cotonou, Bénin \\ Email: "alphonseadite@gmail.com
}

Received 4 April 2016; accepted 16 May 2016; published 19 May 2016

Copyright $@ 2016$ by authors and Scientific Research Publishing Inc.

This work is licensed under the Creative Commons Attribution International License (CC BY). http://creativecommons.org/licenses/by/4.0/

(c) ()

\section{Abstract}

Man-made lakes are alternative and potential habitats for biodiversity conservation, fisheries and extensive aquaculture. We investigated the ecology and the fish community structure of two (2) sand-dragged man-made lakes, Lake Ahozon and Lake Bewacodji of Southern Benin, with implications for species conservation, fisheries management and aquaculture valorization. From August 2014 to July 2015, habitats conditions were evaluated and fishes were sampled monthly with seine, cast net, experimental gill net and hooks in the open water and aquatic vegetation habitats of both lakes. Overall, the water quality of Lake Ahozon was globally favorable for the growth and the survival of the fish resources whereas Lake Bewacodji exhibited a poor water quality indicated mainly by an acid pH (mean: $6.32 \pm 0.58$ ) and low dissolved oxygen concentrations (mean: $3.52 \pm 1.25 \mathrm{mg} / \mathrm{l}$ ) caused by dense floating plants, Nymphea sp mainly and huge daily dumping of domestic wastes. The study revealed low species richness, $d=5.89$ and $d=3.87$, and low species diversity, $\mathrm{H}^{\prime}=0.76$ and $\mathrm{H}^{\prime}=\mathbf{0 . 4 8}$ for Lakes Ahozon and Bewacodji, respectively, with Lake Ahozon more diverse than Lake Bewacodji. The fish community of Lake Ahozon comprised six (6) species, 3 cichlids Sarotherodon galilaeus, Oreochromis niloticus and Tilapia guineensis, the silver catfish, Chrysichthys nigrodigitatus (Claroteidae), the African bonytongue, Heterotis niloticus (Osteoglossidae), and the African catfish, Clarias gariepinus (Clariidae). Numerically, S. galilaeus dominated Lake Ahozon and made $85.21 \%$ of the sample. In Lake Bewacodji, the fish composition comprised four (4) species, Sarotherodon galilaeus multifasciatus, the dominant species making numerically $\mathbf{9 1 . 5 8 \%}$ of the total sample, T. guineensis, C. gariepinus and C. nigrodigitatus. With regard to trophic

${ }^{*}$ Corresponding author.

How to cite this paper: Gbaguidi, H.M.A.G., Adite, A. and Sossoukpe, E. (2016) Ecology and Fish Biodiversity of Man-Made Lakes of Southern Benin (West Africa): Implications for Species Conservation and Fisheries Management. Journal of Environmental Protection, 7, 874-894. http://dx.doi.org/10.4236/jep.2016.76079 
structure, the fish assemblages of both lakes were numerically dominated by planktinovores/ detritivores, mainly $S$. galilaeus, $\boldsymbol{O}$. niloticus, $T$. guineensis and $\boldsymbol{C}$. nigrodigitatus making together 99.46\% of Lake Ahozon fish community, and S. galilaeus multifasciatus, T. guineensis and $C$. nigrodigitatus accounting together for about $98.59 \%$ of Lake Bewacodji. In Lake Ahozon, standard length (SL) frequencies histograms showed an unimodal size distribution for $\boldsymbol{H}$. niloticus, the nile tilapia $O$. niloticus and $C$. gariepinus whereas the two cichlids, $S$. galilaeus and $T$. guineensis exhibited a bimodal size distribution. In Lake Bewacodji, $S$. galilaeus multifasciatus, $C$. nigrodigitatus and $C$. gariepinus exhibited an unimodal size distribution. A sustainable exploitation of both man-made lakes requires the implementation of an integrated management scheme which should include habitat restoration and protection plan, fisheries/aquacultural valorization, ecological sound agriculture/ecotourism and environmental monitoring.

\section{Keywords}

Conservation, Diversity, Domestic Wastes, Fisheries, Habitat Degradation, Management, Man-Made Lakes, Sand-Dragging, Sarotherodon galilaeus

\section{Introduction}

In most region of Africa, fisheries production and yields have drastically decreased and catches per unit of effort (CPUE) have become low in natural water bodies such as rivers, stream, lakes, lagoons etc. [1]-[3]. Major threats were overfishing caused by the increasing fishermen population, grassroots poverty, the use of sophisticated and prohibited fishing gears and fishing techniques, pollution, alteration of water quality, mangrove destructions, habitat losses and degradation, introduction of non-native species, multiple utilizations (agriculture, aquaculture, sand dragging etc.) of water bodies, invasion of floating plants (Eichhornia crassipes), climate changes and modification of flooding regimes [4]-[6]. Therefore, an alternative response is probably the use of various non conventional medium-environments such as the numerous man-made lakes to develop the sector of fisheries and aquaculture in order to reduce the fishing pressures in natural inlands waters and to contribute to ecosystem recovery and species conservation [7]-[9].

In Benin, man-made lakes include 1) few lakes generated from electrical and agricultural projects such as the hydro electrical dams of Nangbeto belonging to Benin and Togo and the hydro agricultural dams of Savè Sugar Company (SOCUBE), 2) constructed small ponds that hold running waters used to supply rearing animals, mainly cows, with drinking water, and 3) man-made lakes originated from sand-dragging activities that supply building enterprises with sand [10]-[12]. This last category appears to be widespread and dominated the man-made lakes in Benin. Indeed, following the excavation of grasslands and dry lands for sand provisions, running waters progressively accumulated in the resulting holes to generate some man-made lakes that were generally neglected, abandoned and considered as useless or lost lands by the owners. Thus, a benefic management of these lakes was scant and most of them underwent daily dumping of domestic wastes that caused lake pollution along with profound changes in water quality and fish community structures [13]-[15]. However, these artificial lakes could be managed to increase inlands fisheries, to develop aquaculture industries, to conserve fish species and to implement other various economical activities that could alleviate poverty and improve grassroots revenues in Benin [16]-[18]. In particular, unlike constructed classic small fishponds of reduced sizes, manmade lakes exhibited relatively large area and could be used as alternative breeding grounds for some species in order to produce juveniles (seeds) to supply fish culture centers with fingerlings. Indeed, some delicate species, such as the African bonytongues, Heterotis niloticus (Osteoglossidae), the silver catfish, Chrysichthys nigrodigitatus (Claroteidae) and the African catfish, Clarias gariepinus (Clariidae) etc., having a high potential in aquaculture, do not reproduce or barely reproduce in captivity in small fishponds [19]-[21]. In particular, to date, no scientific data is available on the captive breeding and on the artificial reproduction of Heterotis niloticus. Therefore, the man-made lakes could be an alternative appropriate medium-environment to experiment the breeding of such species, in order to get fingerlings for aquaculture centers. In general, these species required a relatively large water space under a special hydrologic regime, that is, the succession of low-water and highwater seasons that stimulate gonad maturations and egg hatchings. 
Furthermore, these lakes can serve as fish conservation biota or as a biological reserve, especially for threatened and endangered species [22]-[24]. Such species could be reproduced and the juveniles reintroduced in their natural habitats [25] [26]. Though artificial, these lakes harbor an important naturally-colonized or introduced biodiversity such as aquatic plants, fishes, amphibians, micro invertebrates, insects, mollusks etc. that could serve for scientific researches and environmental education tools [27]. From a quick exploration during the wet season of 2014, Djihouessi [28] reported some fisheries data dominated in both lakes by S. galilaeus. When well managed, these lakes could serve for sustainable and ecological agriculture and ecotourism.

However, despite these various possible utilizations and valorizations of the man-made lakes, little is known about the ecology and the fish community structure of the sand-dragged man-made lakes of Benin. This information is badly needed to implement an integrated management (including fisheries and aquaculture valorization) of the multitude abandoned and neglected man-made lakes of Benin.

The current research was undertaken to study the ecology and the fish community structure of some manmade lakes of Southern Benin (West Africa) with implications for species conservation, fisheries management and aquaculture valorization. Specific objectives were 1) to evaluate the environmental quality of these lakes; 2) to investigate the fish biodiversity and community structures; 3) to evaluate relationships between the environment traits and the fish community indices; and 4) to design an integrated management scheme of the man-made lakes investigated.

\section{Material and Methods}

\subsection{Study Region}

The study area comprised two (2) man-made water bodies, Lake Ahozon $\left(06^{\circ} 22^{\prime} 52^{\prime \prime N}\right.$; $002^{\circ} 10^{\prime} 34$ "E) and Lake Bewacodji (06 23'10"N; 002 12'11"E), both located in Southern Benin, Ouidah City, Pahou County (Figure 1).

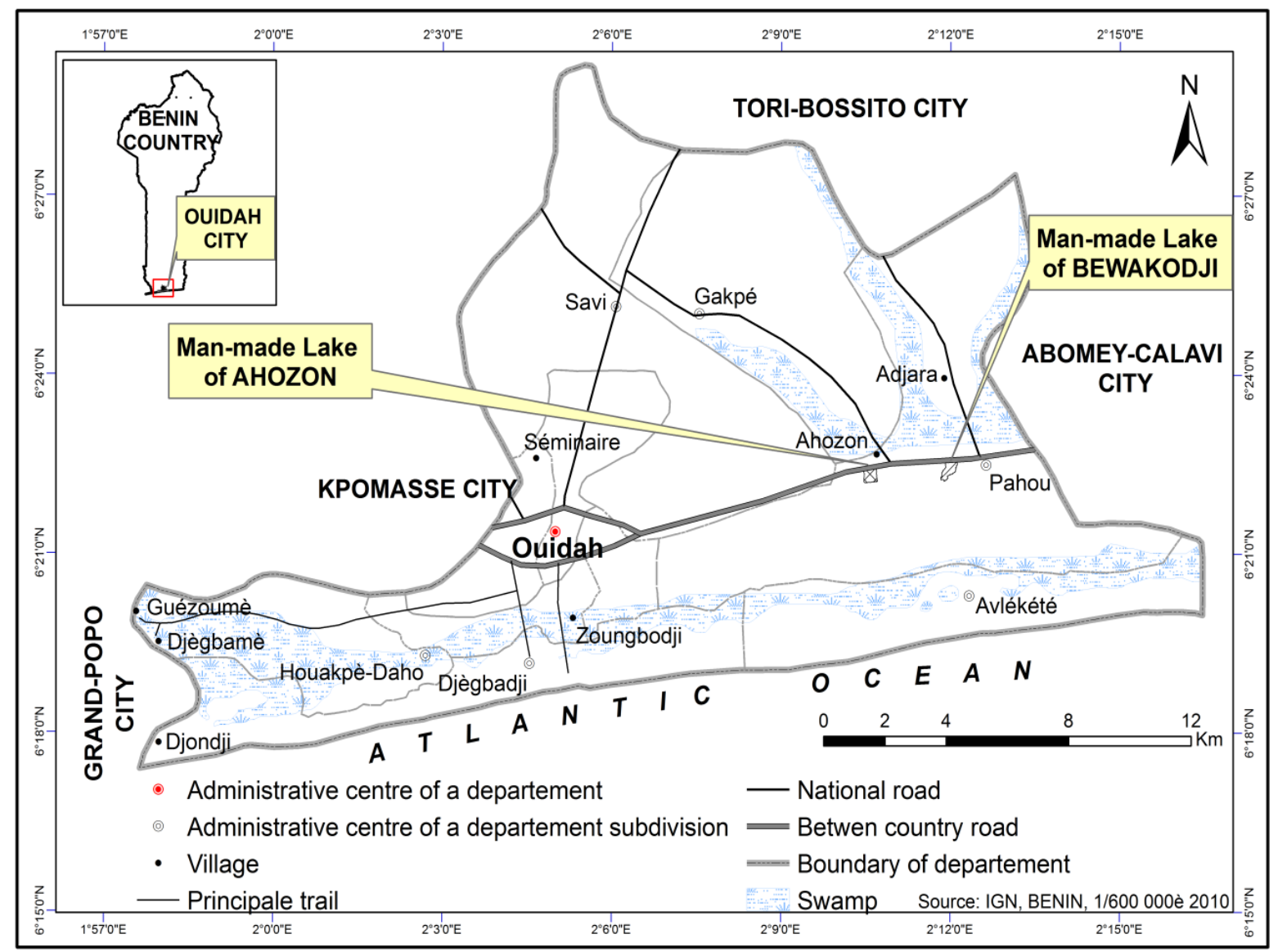

(a) 
H. M. A. G. Gbaguidi et al.

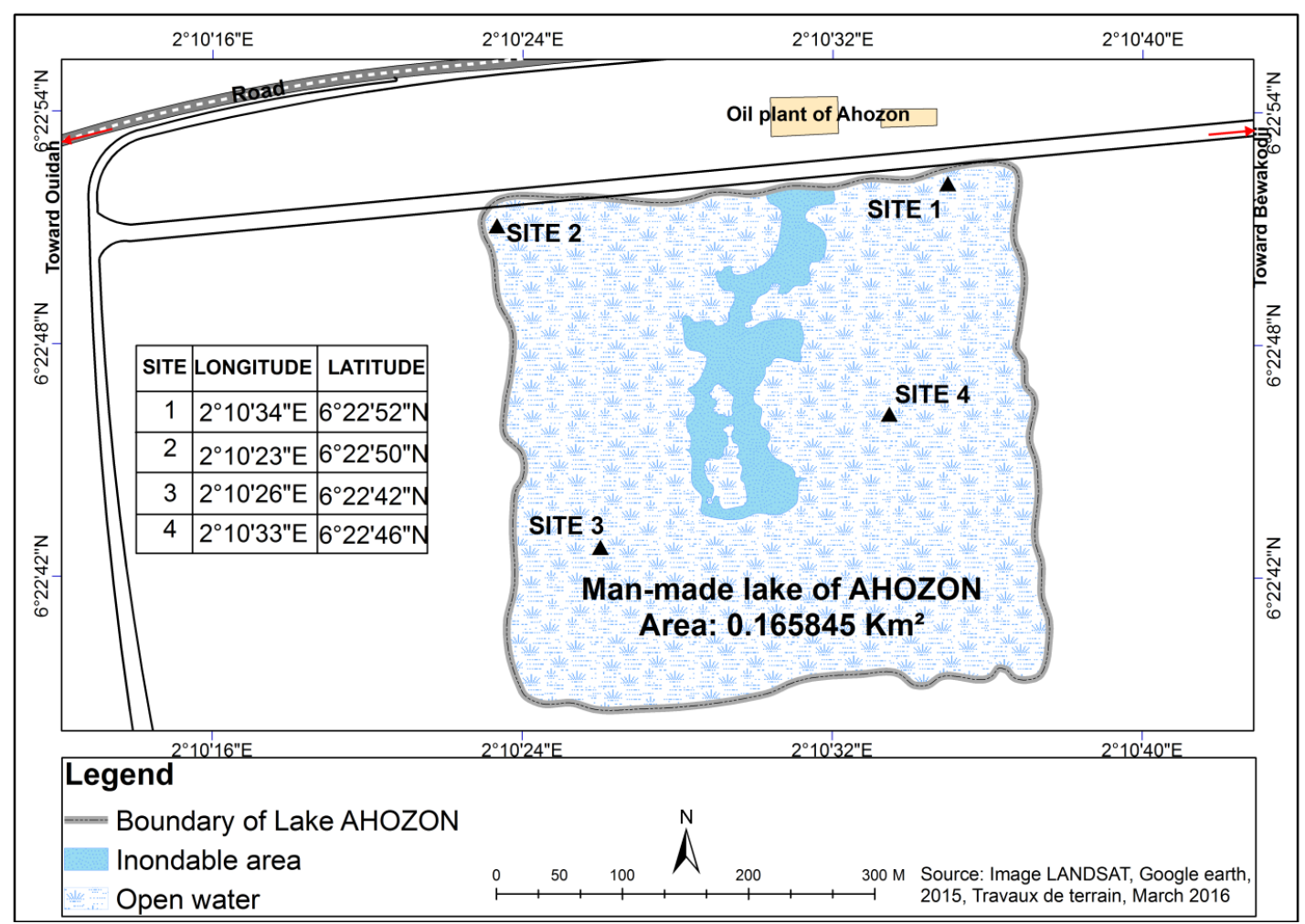

(b)

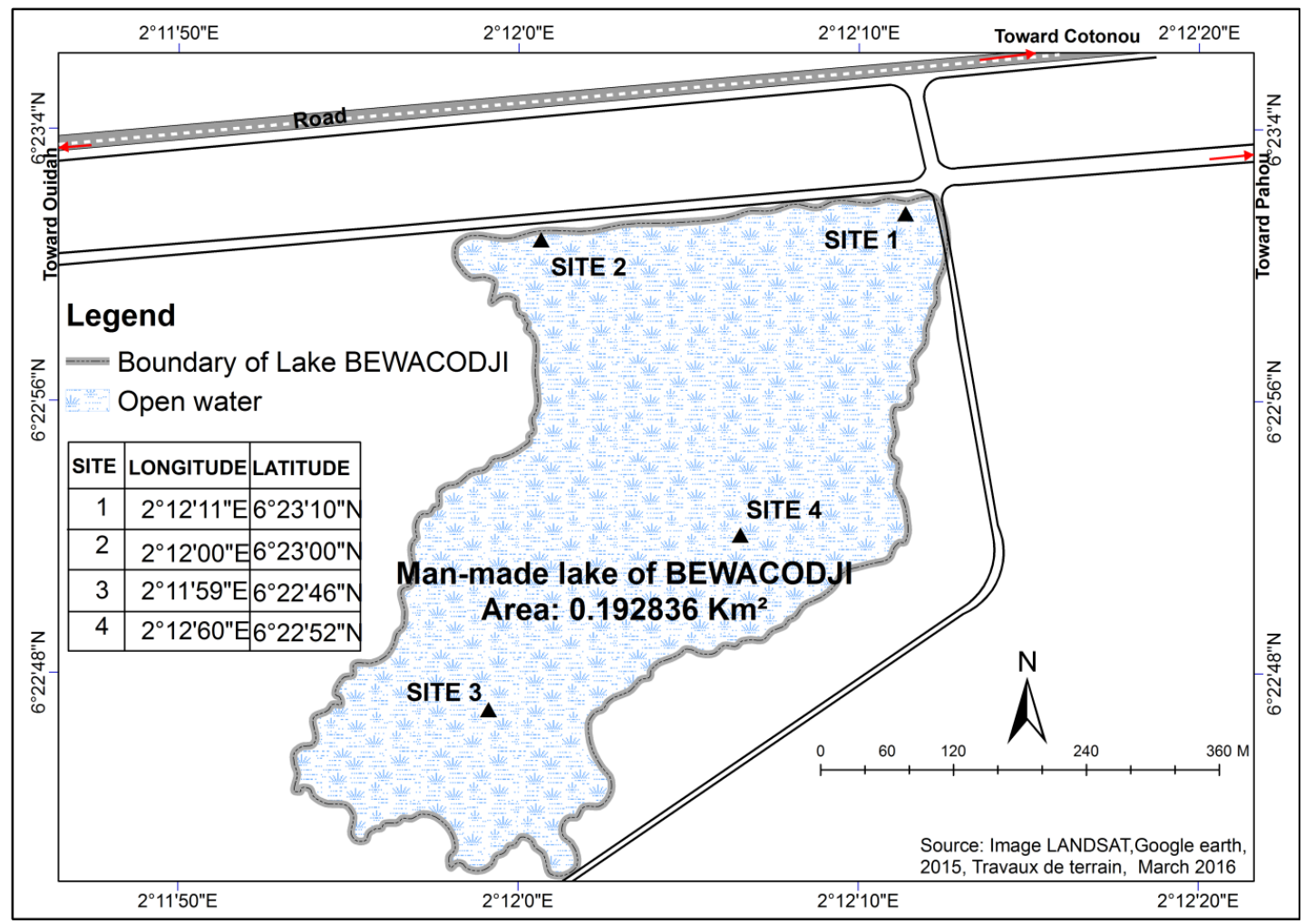

(c)

Figure 1. Map showing: (a) Ouidah City in South-Benin and the two study locations; (b) the man-made lake of Ahozon and (c) the man-made lake of Bewacodji. Site 1 and Site 2 = aquatic vegetation habitats; Site 3 and Site 4 = Open water habitats. 
Ouidah City covers about $364 \mathrm{~km}^{2}$ and has on its South, the Atlantic Ocean and the mangrove-lined coastal lagoon [25]. The climate is sub equatorial with two (2) wet seasons (April to July; mid-September to October) and two (2) dry seasons (December to March; mid-August to mid-September) with a peak usually recorded in June. Yearly mean rainfall reached $1307.3 \mathrm{~mm}$ and ambient temperatures ranged between $25^{\circ} \mathrm{C}$ and $33.6^{\circ} \mathrm{C}$. Monthly evaporation varied between 59.2 - $145 \mathrm{~mm}$ [26] [27]. The study region comprised sandy soils, red ferric soils and a vast swampy land located at the coastal zone and extended from Cotonou City (South-Benin) to Ouidah. Currently, this swamp undergoes permanent sand-dragging activities, considered as an ecological disaster. Plantations such as Elaeis guineensis (palm tree) and Coco nucifera (coconut tree), producing oil for industries, were common in the study region [26] [27]. Also, intense agriculture dominated by corn, tomatoes, beans, groundnuts etc. occurred in the study area. Furthermore, multispecies fisheries dominated Ouidah City and took place in the coastal lagoon and in some freshwater lakes such as Toho-Todougba, Ahouangan and Dati. Though not widespread, fish culture was encountered in the study region with couple of fish ponds constructed in the swamps and wetlands.

\subsection{Description of the Man-Made Lakes}

The two man-made lakes, Lake Ahozon and Lake Bewacodji, about $5 \mathrm{~km}$ apart, are located between two water bodies, Toho-Todougba $\left(15 \mathrm{~km}^{2}\right)$, a freshwater lake, and the coastal lagoon $\left(60 \mathrm{~km}^{2}\right)$, a brackish water. These man-made lakes originated from sand-dragging activities to supply building enterprises with sand. Indeed, because the government has prohibited the exploitation of marine sand, source of severe ecological disasters at the Atlantic seashore, the alternative was the excavation of grasslands, dry lands or even wetlands to get sand. Thus, running waters from rainfall progressively accumulated in the resulting holes to generate artificial lakes, also called man-made lakes. These kinds of lakes are currently widespread, but generally neglected, abandoned, and considered as useless or lost lands by most owners. GPS tracking reveal that Lake Bewacodji (Figure 1) covered about $0.1928 \mathrm{~km}^{2}$ and showed dense floating plants on the surface. In particular, this lake undergoes a daily dumping of domestic wastes that negatively affect the water quality and its productivity. The artificial lake of Ahozon extended on about $0.1658 \mathrm{~km}^{2}$ (Figure 1) and in contrast with Lake Bewacodji, was exempt of floating plants and no domestic waste dumping was recorded during the study period. Dominant phytoplankton genera in Lake Ahozon were Navicula, Peridinium, Scennedesmus, Pinnularia, Spirogyra, Cosmarium, Melosira, Synechocystis, Microcystis, Oscillatoria, Euglena, Phacus, Surirella and Lychmophora. Zooplanktons in Lake Ahozon were dominated by Copepods, Trichocerca, Keratella, Brachiomus and. In Lake Ahozon, benthic macro invertebrates recorded were chironomid larvae and a Gasteropod mollusk, Melanoïde tubercularis. Aquatic vegetation in Lake Ahozon was dominated by Cyperus crassipes, Cyperus rotundus, Fuirena umbellata, Andropogon gayanus, Ludwigia perennis, Emilia praetermissa, Eleocharis complanata, Enydra fluctuans et Mariscus ligularis. In Lake Bewacodji, dominant phytoplanktons were Lychmophora, Spirogyra, Cosmarium, Euglena, Microcystis and Oscillatoria and zooplanktons comprised mainly Daphnia, Tropocyclops, Keratella, Brachiomus and Copepods. Also, aquatic vegetation in lake Bewacodji comprised mainly Ludwigia stolonifera, Utricularia reflexa, Ludwigia octovalois, Ipomea aquatica, Paspalum vaginatum, Nymphaea lotus, Fuirena umbellata, Cyperus articulatus and Andropogon gayanus.

In both lakes, subsistence fisheries occurred and were practiced by a couple of migrant fishermen. Around Lake Ahozon, subsistence agriculture involving maize, salads, beans, carrots lettuce, tomatoes and cucumbers sporadically take place.

\subsection{Sampling Sites}

In both Lakes, Lake Ahozon and Lake Bewacodji, four (4) sampling sites were selected for this study, two sites in the "open water" habitat and two sites in the "aquatic vegetation" habitat (Figure 1). The "open water" habitat exhibited a relatively high depth and high water velocity, but exempt of vegetation. In contrast, the "aquatic vegetation” habitat, the edge of the lake, was shallow and characterized by a low water velocity and relatively dense vegetation.

\subsection{Evaluation of Habitat Characteristics}

The environment conditions of each man-made lake were evaluated. Evaluation were made on soil type, aquatic vegetation, water types, dominant terrestrial habitats, utilization of the lakes and adjacent lands, substrates, 
pollutions, and water physicochemical conditions [28]. Water samples were collected with a hydrobios sampler. Water depth was measured to the nearest millimeter using a graduated rope and turbidity was measured to the nearest millimeter with a secchi disk. Temperature and dissolved oxygen were measured to the nearest $0.1^{\circ} \mathrm{C}$ and $0.1 \mathrm{mg} \cdot \mathrm{l}^{-1}$ respectively, with a digital oxythermometer (Model HANNA), and the $\mathrm{pH}$ was evaluated to the nearest 0.1 with a waterproof $\mathrm{pH}$ meter (Model HANNA). Conductivity was measured to the nearest $1.0 \mu \mathrm{s} / \mathrm{cm}$ with a conductimeter and salinity was measured to the nearest 1\%o with a model VISTA refractometer. Aquatic vegetation was sampled and identifications were made in the Department of Botany of the Faculty of Sciences and Technics at the "Université d'Abomey-Calavi”. Seasonally (flood, dry, wet), phytoplankton and zooplankton were sampled with a planktonic net and the macro invertebrates were collected with a dip net. Phytoplankton, zooplankton and macro invertebrates were identified to the lowest possible taxonomic level using the identification keys of Needham [29].

\subsection{Fish Sample Collection}

Fishes were sampled in the "aquatic vegetation" habitat and in the "open water" habitat using appropriate set of fishing gears and methods so that common fish species would be well represented and samples reflect the relative abundance of the fish community. Likewise, the use of various collecting gears helped not only to increase the likelihood of uncommon species to occur in the fish sample, but also to assess the whole fish biodiversity of these man-made lakes [30]. At the "open water" and "aquatic vegetation" habitats, fishes were sampled twice a month from August 2014 to July 2015 with cast nets (9.80 m-diameter, 4.90 m-height, 40 mm-mesh), seines (4.15 m-length $\times 1.77 \mathrm{~m}$-width, $3 \mathrm{~mm}$-mesh), hooks (90 m-length) and experimental gill net (40 m × $1.05 \mathrm{~m}, 40$ $\mathrm{mm}$ mesh). Cast nets were used in the "open water" with the help of fishermen. The net, once casted covers a defined area, then the cast net was pulled out delicately in the boat and all trapped fishes were then removed by hands. Seine hauls in marginal aquatic vegetation were made by setting the seine stationary, and kicking the vegetation to drive the fish in to the net before lifting it [5]. At each sampling site, ten rounds of seining were done. Hooks and gill nets were set in the "open water", yet, contribute very little to the total sample. Samplings with gill nets and hooks were made by attaching the net to the sticks and left it for 12 hours. Aggregated samples from cast nets, seining, gill nets and hooks were gathered to assess the whole fish assemblages of these manmade lakes.

Once caught, the fish samples were identified, measured, weighted and preserved in situ in 10\% formalin. Species identification was based on references such as Leveque et al. [31], Van Thielen et al. [32], and Lowe McConnell [33]. The fish samples were then transported to the "Laboratoire d' Ecologie et de Management des Ecosystèmes Aquatiques" and preserved in $70 \%$ ethanol for further observation on the feeding ecology and some aspects of the reproductive ecology of keys species.

\subsection{Data Analysis}

Both physicochemical and fish community data were recorded in SPSS spreadsheet [34]. Means, ranges and standard deviations of physicochemical features were computed and recapitulated on a table. Relative to fish community data, size ranges and means of fish standard length (SL) and weight (W) were computed using SPSS computer software [34]. Species abundance and relative abundance were computed to indicate the numerical importance of each species in the sample. Species richness $(d)$ was determined following Margalef index [35]:

$$
d=S-1 / \ln N
$$

where $S$ is the number of species, and $N$ the number of individuals in the sample. Species diversity $\left(H^{\prime}\right)$ was determined following Shannon \& Weaver index of diversity [36]:

$$
H^{\prime}=-\sum\left(p_{i}\right) * \log _{2}\left(p_{i}\right)
$$

where $H^{\prime}$ is the index of species diversity, $p_{i}=n_{i} / N$, the proportion of total sample belonging to ith species, $n_{i}$ the number of individuals of each species in the sample, $N$ the total number of individuals of all species in the sample. The evenness measure ( $J^{\prime}$ ) of Shannon \& Weaver [36] was computed following the formula:

$$
J^{\prime}=H^{\prime} / \log _{2} S
$$

where $H^{\prime}$ is the Shannon \& Weaver index [36] of diversity, $S$ is the number of species in the sample. For this 
study, these three indexes (richness, diversity, evenness) were computed for each habitat. I used SPSS computer program [34] to generate species diversity, species richness and evenness indexes.

The trophic structure of the fish community was determined by categorizing fishes in five trophic categories, 1) detritivores, 2) planktinovores/microcarnivores, 3) herbivores, 4) intermediate carnivores and 5) top-carnivores [3] [12]. Previous studies from Halliday \&Young [37], Adite \& Winemiller [38], on diet were used for this classification. The importance of each trophic category was appreciated using the relative abundance of fish species. Relationships between the fish community traits and the physicochemical features were explored through linear regression models and F-test. Frequency histograms of fish standard length were constructed by habitat type for dominant species.

\section{Results}

\subsection{Hydrology and Water Characteristics}

The two man-made lakes, Lake Ahozon and Lake Bewakodji, originated from the excavation of grasslands and dry lands, consequently, water accumulation and hydrological regime depended solely on rainfall and running waters. Both water bodies were freshwater lakes and lacked connection with coastal brackish waters and any other freshwater lakes. However, these man-made lakes are located about $5 \mathrm{~km}$ from a natural freshwater lake, Toho-Todougba Lagoon $\left(16 \mathrm{~km}^{2}\right)$. Both lakes showed sandy-muddy bottoms with dominance of sand in Lake Ahozon. In general, significant variations $(p<0.05)$ were recorded between the water quality of both lakes.

In the man-made lake of Ahozon, depths varied from 16.2 to $240 \mathrm{~cm}$ (mean: $80.19 \mathrm{~cm}$ ), transparencies from 16.2 to $60.5 \mathrm{~cm}$ (mean: $36.63 \mathrm{~cm}$ ). Water temperatures ranged between $28.2^{\circ} \mathrm{C}$ and $38.7^{\circ} \mathrm{C}$ (mean: $33.25^{\circ} \mathrm{C}$ ), $\mathrm{pH}$ between 6.7 and 9.7 (mean: 7.51), dissolved oxygen concentrations between 0.73 and $11.8 \mathrm{mg} / \mathrm{l}$ (mean: 5.43 $\mathrm{mg} / \mathrm{l}$ ), and conductivitiy between 50 and $560 \mu / \mathrm{cm}$ (mean: $240 \mu / \mathrm{cm}$ ) (Table 1). In Lake of Bewacodji, depths varied from 31.1 to $95.5 \mathrm{~cm}$ (mean: $67.99 \mathrm{~cm}$ ), transparencies from 31.1 to $95.5 \mathrm{~cm}$ (mean: $53.83 \mathrm{~cm}$ ). Water temperatures ranged between $28.8^{\circ} \mathrm{C}$ and $37.9^{\circ} \mathrm{C}$ (mean: $33.41^{\circ} \mathrm{C}$ ), pH between 5.2 and 7.1 (mean: 6.32), dissolved oxygen between 1.32 and $5.53 \mathrm{mg} / \mathrm{l}$ (mean: $3.52 \mathrm{mg} / \mathrm{l}$ ), and conductivity between 30 and $410 \mu / \mathrm{cm}$ (mean: $146 \mu / \mathrm{cm}$ ) (Table 1).

In both man-made lakes, significant spatial variations $(p \leq 0.001)$ of physicochemical parameters were recorded. Indeed, except conductivity, the remaining water features, namely depth, transparency, temperature, dissolved oxygen, percent saturation, and $\mathrm{pH}$ values were higher in the open water habitat than in the aquatic vegetation habitat (Table 1). Likewise, seasonal variations of the water features were recorded in both Lakes with depths and transparencies higher in wet season in Lake Ahozon where they reached $240 \mathrm{~cm}$ and $60.5 \mathrm{~cm}$, respectively. In Lake Bewacodji, depths and transparencies were higher in the flood season and reached $95.5 \mathrm{~cm}$ and $65.5 \mathrm{~cm}$, respectively. Inversely, temperatures were higher during the dry periods in both lakes and reached $38.7^{\circ} \mathrm{C}$ and $37.8^{\circ} \mathrm{C}$ in Lake Ahozon and Lake Bewacodji, respectively.

\subsection{Fish Community Composition and Abundance}

A total of 8845 individual fishes were sampled from both artificial lakes during the study period, August 2014 July 2015.

Table 1. Ranges and mean values ( \pm SD) of the water parameters measured from August 2014 to July 2015 in the man-made lakes of Ahozon and Bewacodji in Ouidah city, Southern Benin.

\begin{tabular}{|c|c|c|c|c|c|c|}
\hline \multirow{2}{*}{$\begin{array}{c}\text { Physicochemical } \\
\text { parameters }\end{array}$} & \multicolumn{3}{|c|}{ Artificial lake of Ahozon } & \multicolumn{3}{|c|}{ Artificial lake of Bewacodji } \\
\hline & Mean & Range & $\pm \mathrm{SD}$ & Mean & Range & $\pm \mathrm{SD}$ \\
\hline Depth (cm) & 80.19 & $16.2-240$ & 56.82 & 67.99 & $31.1-95.5$ & 15.33 \\
\hline Transparency (cm) & 36.63 & $16.2-60.5$ & 11.18 & 55.83 & $31.1-95.5$ & 14.69 \\
\hline Temperature $\left({ }^{\circ} \mathrm{C}\right)$ & 33.25 & $28.2-38.7$ & 2.50 & 33.41 & $28.8-37.9$ & 2.87 \\
\hline $\mathrm{pH}$ & 7.51 & $6.7-9.7$ & 0.78 & 6.32 & $5.2-7.1$ & 0.58 \\
\hline Dissolved oxygen (mg/l) & 5.43 & $0.73-11.8$ & 2.52 & 3.52 & $1.32-5.53$ & 1.25 \\
\hline $\mathrm{O}_{2}$ percent of saturation (\%) & 82.69 & $10.5-208.8$ & 41.63 & 51.75 & $19.2-84.9$ & 19.62 \\
\hline Conductivity $(\mu / \mathrm{cm})$ & 240 & $50-560$ & 118.40 & 146 & $30-410$ & 99.76 \\
\hline
\end{tabular}


Man-made lake of Ahozon: In this lake, 6506 individual fishes comprising 6 species belonging to 6 genera and 4 families were collected (Table 2). Among them, the family Cichlidae was the most speciose and comprised Sarotherodon galilaeus, Oreochromis niloticus, Tilapia guineensis. In addition, the fish community of Lake Ahozon comprised the silver catfish, Chrysichthys nigrodigitatus (Claroteidae), the African bonytongue, Heterotis niloticus (Osteoglossidae), and the African catfish, Clarias gariepinus (Clariidae). Spatially, the "open water" habitat, with six (6) species, was more diverse than the aquatic vegetation harboring four (4) species (Table 3 and Table 4).

Likewise, numerically, cichlids dominated the sample and accounted together for $88.26 \%$ with S. galilaeus, a naturally-colonized species of Lake Ahozon, making alone $85.21 \%$ of the total sample, followed by the newly introduced cichlid O. niloticus (2.18\%), and T. guineensis (0.75\%), an occasional tilapine species. The second species numerically most important in Lake Ahozon was the introduced claroteid, C. nigrodigitatus accounting for about $11.22 \%$ of the total sample. The newly introduced osteoglossid, H. niloticus (0.52\%) and the African catfish C. gariepinus (0.02\%) were sporadically recorded in the sample.

Table 2. Fish species composition, abundance, size range and mean, weight range and mean, of the fishes in the man-made lake of Ahozon, Ouidah city, Southern Benin.

\begin{tabular}{|c|c|c|c|c|c|c|}
\hline Family \& Species & Abundance & $\begin{array}{c}\text { Relative } \\
\text { abundance (\%) }\end{array}$ & $\begin{array}{l}\text { SL mean } \\
(\mathbf{m m})\end{array}$ & $\begin{array}{l}\text { SL range } \\
(\mathbf{m m})\end{array}$ & $\begin{array}{l}\text { Weight mean } \\
\text { (g) }\end{array}$ & $\begin{array}{l}\text { Weight range } \\
\text { (g) }\end{array}$ \\
\hline \multicolumn{7}{|l|}{ Cichlidae } \\
\hline Oreochromis niloticus & 142 & 2.18 & 64.25 & $28-182$ & 15.64 & $0.2-110$ \\
\hline Sarotherodon galilaeus & 5550 & 85.31 & 56.57 & $8-192$ & 14.38 & $0.01-190$ \\
\hline Tilapia guineensis & 49 & 0.75 & 47.49 & $20-96$ & 9.71 & $0.3-448$ \\
\hline \multicolumn{7}{|l|}{ Clariidae } \\
\hline Clarias gariepinus & 1 & 0.02 & 506 & $506-506$ & 1328 & $1328-1328$ \\
\hline \multicolumn{7}{|l|}{ Claroteidae } \\
\hline Chrysichthys nigrodigitatus & 730 & 11.22 & 127.10 & $55-262$ & 57.95 & $4-469.7$ \\
\hline \multicolumn{7}{|l|}{ Osteoglossidae } \\
\hline Heterotis niloticus & 34 & 0.52 & 332.24 & $54-660$ & 523.69 & $2.5-3100$ \\
\hline $\begin{array}{l}\text { Total number of individuals: } 650 \\
\text { Total number of families: } 4 \\
\text { Total number of species: } 6\end{array}$ & & & & & & \\
\hline
\end{tabular}

Table 3. Fish species composition, abundance, size range and mean, weight range and mean, of the fishes in the "open water" habitat of the man-made lake of Ahozon, Ouidah city, Southern Benin.

\begin{tabular}{|c|c|c|c|c|c|c|}
\hline Family \& Species & Abundance & $\begin{array}{c}\text { Relative } \\
\text { abundance (\%) }\end{array}$ & $\begin{array}{l}\text { SL mean } \\
(\mathrm{mm})\end{array}$ & $\begin{array}{l}\text { SL range } \\
(\mathrm{mm})\end{array}$ & $\begin{array}{c}\text { Weight mean } \\
\text { (g) }\end{array}$ & $\begin{array}{c}\text { Weight range } \\
\text { (g) }\end{array}$ \\
\hline \multicolumn{7}{|l|}{ Cichlidae } \\
\hline Oreochromis niloticus & 109 & 2.40 & 67.20 & $29-182$ & 17.28 & $0.2-110$ \\
\hline Sarotherodon galilaeus & 3674 & 88.89 & 75.93 & $17-192$ & 21.50 & $0.4-190$ \\
\hline Tilapia guineensis & 18 & 0.40 & 78.56 & $66-96$ & 23.83 & $12.9-44.8$ \\
\hline \multicolumn{7}{|l|}{ Clariidae } \\
\hline Clarias gariepinus & 1 & 0.02 & 506 & 506 & 1328 & 1328 \\
\hline \multicolumn{7}{|l|}{ Claroteidae } \\
\hline Chrysichthys nigrodigitatus & 730 & 16.07 & 127.10 & $55-262$ & 57.95 & $4-469.7$ \\
\hline \multicolumn{7}{|l|}{ Osteoglossidae } \\
\hline Heterotis niloticus & 10 & 0.22 & 396.1 & $302-660$ & 757.56 & $230-3100$ \\
\hline $\begin{array}{l}\text { Total number of individuals: } 454 \\
\text { Total number of families: } 4 \\
\text { Total number of species: } 6\end{array}$ & & & & & & \\
\hline
\end{tabular}


Table 4. Fish species composition, abundance, size range and mean, weight range and mean, of the fishes in the "aquatic vegetation" habitat of the man-made lake of Ahozon, Ouidah city, Southern Benin.

\begin{tabular}{|c|c|c|c|c|c|c|}
\hline Family \& Species & Abundance & $\begin{array}{c}\text { Relative } \\
\text { abundance (\%) }\end{array}$ & $\begin{array}{c}\text { SL mean } \\
(\mathbf{m m}))\end{array}$ & $\begin{array}{c}\text { SL range } \\
(\mathbf{m m}\end{array}$ & $\begin{array}{l}\text { Weight mean } \\
\text { (g) }\end{array}$ & $\begin{array}{c}\text { Weight range } \\
\text { (g) }\end{array}$ \\
\hline \multicolumn{7}{|l|}{ Cichlidae } \\
\hline Oreochromis niloticus & 33 & 1.68 & 54.51 & $28-100$ & 10.25 & $0.6-36.9$ \\
\hline Sarotherodon galilaeus & 1876 & 95.52 & 18.65 & $8-76$ & 0.43 & $0.01-17.9$ \\
\hline Tilapia guineensis & 31 & 1.58 & 29.45 & $20-49$ & 1.51 & $0.3-6.2$ \\
\hline \multicolumn{7}{|l|}{ Osteoglossidae } \\
\hline Heterotis niloticus & 24 & 1.22 & 305.75 & $54-605$ & 426.25 & $2.5-2700$ \\
\hline $\begin{array}{l}\text { Total number of individuals: } \\
\text { Total number of families: } 2 \\
\text { Total number of species: } 4\end{array}$ & & & & & & \\
\hline
\end{tabular}

Table 5. Fish species composition, abundance, size range and mean, weight range and mean, of the fishes in the man-made lake of Bewacodji, Ouidah city, Southern Benin.

\begin{tabular}{|c|c|c|c|c|c|c|}
\hline Family \& Species & Abundance & $\begin{array}{c}\text { Relative } \\
\text { abundance (\%) }\end{array}$ & $\begin{array}{c}\text { SL mean } \\
(\mathbf{m m}))\end{array}$ & $\begin{array}{l}\text { SL range } \\
(\mathbf{m m}\end{array}$ & $\begin{array}{l}\text { Weight mean } \\
\text { (g) }\end{array}$ & $\begin{array}{c}\text { Weight range } \\
\text { (g) }\end{array}$ \\
\hline \multicolumn{7}{|l|}{ Cichlidae } \\
\hline Sarotherodon galilaeus m.* & 2142 & 91.58 & 44.90 & $20-129$ & 4.89 & $0.2-59.8$ \\
\hline Tilapia guineensis & 1 & 0.04 & 54 & $54-54$ & 7.40 & $7.4-7.4$ \\
\hline \multicolumn{7}{|l|}{ Clariidae } \\
\hline Clarias gariepinus & 33 & 1.41 & 153.48 & $110-264$ & 51.79 & $13.1-217.3$ \\
\hline \multicolumn{7}{|l|}{ Claroteidae } \\
\hline Chrysichthys nigrodigitatus & 163 & 6.97 & 100.90 & $41-148$ & 28.39 & $2.3-90.7$ \\
\hline $\begin{array}{l}\text { Total number of individuals: } 233 \\
\text { Total number of families: } 3 \\
\text { Total number of species: } 4\end{array}$ & & & & & & \\
\hline
\end{tabular}

In term of biomass, the 6506 individual fishes sampled in lake Ahozon weighted 143,913.11 grams with $132,498.58$ (92.07\%) in the "open water" habitat and 11,414.53 grams (7.93\%) in the "aquatic vegetation" habitat. S. galilaeus dominated the biomass and alone contributed for about $55.46 \%$ of the total catches, followed by C. nigrodigitatus (29.40\%), H. niloticus (12.37\%). The remaining biomass $(2.78 \%)$ was shared by three (3) species O. niloticus (1.54\%), C. gariepinus (0.92\%), and T. guineensis (0.33\%).

Man-made lake of Bewacodji: In the man-made lake of Bewacodji, 2339 individual fishes comprising 4 species belonging to 4 genera and 3 families were collected (Table 5). The fish composition included two (2) cichlids, Sarotherodon galilaeus multifasciatus and Tilapia guineensis, the African catfish, C. gariepinus (Clariidae) and the silver catfish, C. nigrodigitatus (Claroteidae). Like Lake Ahozon, cichlids numerically dominated the fish community of Lake Bewacodji, and accounted together for $91.62 \%$, with S. galilaeus multifasciatus, the dominant species, making alone $91.58 \%$ of the fish assemblages, followed by the introduced claroteid, C. nigrodigitatus (6.97\%), C. gariepinus $(1.41 \%)$ and $T$. guineensis $(0.04 \%)$ sporadically recorded in the samples.

In term of biomass, the 2339 individual fishes collected in Lake Bewacodji weighted 16,823.7 grams with 8563 grams (50.90\%) in the "open water" and 8260.7 grams (49.10\%) in the "aquatic vegetation" habitat (Tables 5-7). S. galilaeus multifasciatus dominated the biomass and alone contributed for about $62.26 \%$ of the total biomass followed by C. nigrodigitatus (27.51\%), C. gariepinus (10.16\%), and T. guineensis (0.04\%).

\subsection{Diversity, Richness and Evenness Indices}

In general, species richness and diversity indices were low in both man-made lakes. In Lake Ahozon, the Margalef index (d) [35] of species richness computed from aggregated habitats and samples was $d=5.89$. The species 
Table 6. Fish species composition, abundance, size range and mean, weight range and mean, of the fishes in the "open water" of the man-made lake of Bewacodji, Ouidah city, Southern Benin.

\begin{tabular}{|c|c|c|c|c|c|c|}
\hline Family \& Species & Abundance & $\begin{array}{c}\text { Relative } \\
\text { abundance (\%) }\end{array}$ & $\begin{array}{c}\text { SL mean } \\
(\mathrm{mm}))\end{array}$ & $\begin{array}{l}\text { SL range } \\
(\mathrm{mm})\end{array}$ & $\begin{array}{c}\text { Weight mean } \\
\text { (g) }\end{array}$ & $\begin{array}{c}\text { Weight range } \\
\text { (g) }\end{array}$ \\
\hline \multicolumn{7}{|l|}{ Cichlidae } \\
\hline Sarotherodon galilaeus m. & 1193 & 95.21 & 43.00 & $20-129$ & 4.72 & $0.2-59.8$ \\
\hline \multicolumn{7}{|l|}{ Clariidae } \\
\hline Clarias gariepinus & 2 & 0.16 & 203.5 & $143-264$ & 126.85 & $36.4-217.3$ \\
\hline \multicolumn{7}{|l|}{ Claroteidae } \\
\hline Chrysichthys nigrodigitatus & 58 & 4.63 & 117.86 & $94-148$ & 40.94 & $23.2-90.7$ \\
\hline $\begin{array}{l}\text { Total number of individuals: } 125 \\
\text { Total number of families: } 3 \\
\text { Total number of species: } 3\end{array}$ & & & & & & \\
\hline
\end{tabular}

Table 7. Fish species composition, abundance, size range and mean, weight range and mean, of the fishes in the "aquatic vegetation" of the man-made lake of Bewacodji, Ouidah city, Southern Benin.

\begin{tabular}{|c|c|c|c|c|c|c|}
\hline Family \& Species & Abundance & $\begin{array}{c}\text { Relative } \\
\text { abundance (\%) }\end{array}$ & $\begin{array}{l}\text { SL mean } \\
(\mathbf{m m}))\end{array}$ & $\begin{array}{l}\text { SL range } \\
(\mathrm{mm})\end{array}$ & $\begin{array}{l}\text { Weight mean } \\
\text { (g) }\end{array}$ & $\begin{array}{l}\text { Weight range } \\
\text { (g) }\end{array}$ \\
\hline \multicolumn{7}{|l|}{ Cichlidae } \\
\hline Sarotherodon galilaeus m. & 949 & 87.38 & 47.28 & $29-104$ & 5.11 & $13-52.2$ \\
\hline Tilapia guineensis & 1 & 0.09 & 54 & $54-54$ & 7.4 & $7.4-7.4$ \\
\hline \multicolumn{7}{|l|}{ Clariidae } \\
\hline Clarias gariepinus & 31 & 2.85 & 150.26 & $110-196$ & 46.95 & $13.1-109$ \\
\hline \multicolumn{7}{|l|}{ Claroteidae } \\
\hline Chrysichthys nigrodigitatus & 105 & 9.67 & 91.52 & $41-123$ & 21.45 & $2.3-48.4$ \\
\hline $\begin{array}{l}\text { Total number of individuals: } 108 \\
\text { Total number of families: } 3 \\
\text { Total number of species: } 4\end{array}$ & & & & & & \\
\hline
\end{tabular}

richness was higher in the open water $(\mathrm{d}=5.88)$ than in the aquatic vegetation $(\mathrm{d}=3.87)$. Also, the Shannon-Weaver index $\left(\mathrm{H}^{\prime}\right)$ [36] of species diversity of the whole community was low $\left(\mathrm{H}^{\prime}=0.76\right)$ along with a low Evenness $\left(\mathrm{J}^{\prime}=0.43\right)$ (Table 8). However, the $\mathrm{H}^{\prime}=0.85$ record in the open water was higher than that of the aquatic vegetation $\left(\mathrm{H}^{\prime}=0.33\right)$. With regard to season, the computed Shannon-Weaver index $\left(\mathrm{H}^{\prime}=0.55\right)$ for the dry period was higher than those of wet and flood period with reduced evenness indexes varying between 0.11 0.24 (Table 9). Also, the Shannon-Weaver indexes [36] computed for the fishing gears showed H' ranging between 0.03 for hooks and 1.68 for gillnets with Evenness (J') ranging between 0.11 and 0.98 (Table 10).

In Lake Bewacodji, the Margalef index (d) [35] of species richness computed from aggregated habitats was d $=3.87$. Unlike Lake Ahozon, the species richness in Lake Bewacodji was higher in the "aquatic vegetation" $(\mathrm{d}=$ 3.86) compared to that of the "open water" $(d=2.86)$. Likewise, the Shannon-Weaver index [36] of species diversity of the whole community was low $\left(\mathrm{H}^{\prime}=0.48\right)$ with a low Evenness $\left(\mathrm{J}^{\prime}=0.35\right)$ (Table 8). However, the H' $=0.65$ record in the aquatic vegetation was higher than that of the open water $\left(\mathrm{H}^{\prime}=0.28\right)$ (Table 8). With regard to season, the Shannon-Weaver index H' $=0.18$ [36] for the dry period was lower than those of wet and flood period with reduced Evenness indexes varying between 0.18 - 0.37 (Table 11). Also, the computed ShannonWeaver index [36] for the fishing gears showed H' ranging between 0.45 for trap and 1.00 for hooks with Evenness (J') between 0.23 and 0.99 (Table 12).

\subsection{Trophic Structure of Fishes}

The fish communities of both artificial lakes were numerically dominated by planktinovores/detritivores. In the 
Table 8. Fish abundances and diversity indices by habitat type in the man-made lakes of Ahozon and Bewacodji, Ouidah city, Southern Benin.

\begin{tabular}{|c|c|c|c|c|c|c|}
\hline \multirow{2}{*}{ Community features } & \multicolumn{3}{|c|}{ Artificial lake of Ahozon } & \multicolumn{3}{|c|}{ Artificial lake of Bewacodji } \\
\hline & Aquatic vegetation & Open water & Total & Aquatic vegetation & Open water & Total \\
\hline Number of families & 2 & 4 & 4 & 3 & 3 & 4 \\
\hline Number of species & 4 & 6 & 6 & 4 & 3 & 4 \\
\hline Abundance (Sample size) & 1964 & 4542 & 6506 & 1086 & 1253 & 2339 \\
\hline Relative abundance (\%) & 30.19 & 69.81 & 100 & 46.43 & 53.57 & 100 \\
\hline Total weight (g) & $11,414.53$ & $132,498.58$ & $143,913.11$ & 8563 & 8260.7 & $16,823.7$ \\
\hline Percentage weight (\%) & 7.93 & 92.07 & 100 & 50.90 & 49.10 & 100 \\
\hline Margalef index (d) & 3.87 & 5.88 & 5.89 & 3.86 & 2.86 & 3.87 \\
\hline Shannon \& weaver index (H’) & 0.33 & 0.85 & 0.76 & 0.65 & 0.28 & 0.48 \\
\hline Evenness (J') & 0.24 & 0.47 & 0.43 & 0.47 & 0.25 & 0.35 \\
\hline
\end{tabular}

Table 9. Fish abundances and diversity indices by season in the man-made lake of Ahozon, Ouidah city, Southern Benin.

\begin{tabular}{ccccc}
\hline Season & Number of species & Abundance (Number of individuals) & Shannon-Weaver diversity indices (H') & Evenness (J') \\
\hline Flood & 5 & 1575 & 0.28 & 0.12 \\
Dry & 5 & 1637 & 0.55 & 0.24 \\
Wet & 6 & 3294 & 0.29 & 0.11 \\
Total & $\mathbf{6}$ & $\mathbf{6 5 0 6}$ & $\mathbf{0 . 7 6}$ & $\mathbf{0 . 2 4}$ \\
\hline
\end{tabular}

Table 10. Fish abundances and diversity indices by fishing gears in the man-made lake of Ahozon, Ouidah city, Southern Benin.

\begin{tabular}{ccccc}
\hline Fishing gears & Number of species & $\begin{array}{c}\text { Abundance } \\
\text { (Number of individuals) }\end{array}$ & $\begin{array}{c}\text { Shannon-Weaver diversity indices (H') } \\
\text { Evenness (J') }\end{array}$ \\
\hline Cast net & 4 & 3731 & 0.22 & 0.11 \\
Gill net & 4 & 100 & 1.68 & 0.84 \\
Seine & 2 & 1907 & 0.12 & 0.12 \\
Longline & 3 & 711 & 0.03 & 0.02 \\
Trap & 2 & 57 & 0.98 & 0.98 \\
Total & $\mathbf{6}$ & $\mathbf{6 5 0 6}$ & $\mathbf{0 . 7 6}$ & $\mathbf{0 . 2 9}$ \\
\hline
\end{tabular}

Table 11. Fish abundances and diversity indices by season in the man-made lake of Bewacodji, Ouidah city, Southern Benin.

\begin{tabular}{ccccc}
\hline Season & Number of species & Abundance (Number of individuals) & Shannon-Weaver diversity indices (H') & Evenness (J') \\
\hline Flood & 4 & 929 & 0.70 & 0.35 \\
Dry & 2 & 505 & 0.18 & 0.18 \\
Wet & 2 & 905 & 0.37 & 0.37 \\
Total & $\mathbf{4}$ & $\mathbf{2 3 3 9}$ & $\mathbf{0 . 4 8}$ & $\mathbf{0 . 2 4}$ \\
\hline
\end{tabular}

Table 12. Fish abundances and diversity indices by fishing gear in the man-made lake of Bewacodji, Ouidah city, Southern Benin.

\begin{tabular}{|c|c|c|c|c|}
\hline $\begin{array}{l}\text { Fishing } \\
\text { gears }\end{array}$ & $\begin{array}{l}\text { Number of } \\
\text { species }\end{array}$ & $\begin{array}{l}\text { Abundance (Number of } \\
\text { individuals) }\end{array}$ & $\begin{array}{c}\text { Shannon-Weaver diversity indices } \\
\text { (H') }\end{array}$ & $\begin{array}{l}\text { Evenness } \\
\text { (J') }\end{array}$ \\
\hline Longline & 2 & 19 & 1.00 & 0.99 \\
\hline Trap & 4 & 2320 & 0.45 & 0.23 \\
\hline Total & 4 & 2339 & 0.48 & 0.24 \\
\hline
\end{tabular}


man-made lake of Ahozon, planktinovores/detritivores species, mainly S. galilaeus, O. niloticus, Tilapia guineensis and C. nigrodigitatus made together $99.46 \%$ of the total biomass (Table 13). The omnivore and intermediate carnivore were trivial in the fish community and made numerically together only $0.54 \%$. Also, in terms of biomass, planktinovores/detritivores dominated the fish community with $86.71 \%$ of the total biomass followed by the omnivore, $H$. niloticus (12.37\%) and the intermediate carnivore, C. gariepinus, accounted only for $0.92 \%$ of the total biomass.

Like Lake Ahozon, the fish community of the man-made lake of Bewacodji was numerically dominated by planktinovores/detritivores species, mainly S. galilaeus multifasciatus, Tilapia guineensis and C. nigrodigitatus making together $98.59 \%$ of the total sample (Table 14). The intermediate carnivore, C. gariepinus, was trivial in the fish community and made numerically only $1.41 \%$ of the sample. Also, in terms of biomass, planktinovores/ detritivores dominated the fish community with $89.83 \%$ of the total biomass. The intermediate carnivore, C. gariepinus, though not numerically abundant, accounted for $10.17 \%$ of the total biomass.

\subsection{Size Distributions}

In both lakes, individual fish size varied according to species and habitats. In the artificial lake of Ahozon the fish standard lengths (SL) ranged from $8 \mathrm{~mm}$ for S. galilaeus to $660 \mathrm{~mm}$ for H. niloticus and their corresponding weights were $0.3 \mathrm{~g}$ and $3100 \mathrm{~g}$, respectively (Table 2). Larger sizes were mostly found in the "open water" habitat whereas smaller sizes were mostly recorded in the "aquatic vegetation". Three (3) larger species, the African bonytongue $H$. niloticus, the African catfish $C$. gariepinus and the silver catfish, $C$. nigrodigitatus were recorded in the fish community. Standard length (SL) frequencies histograms established for dominant species showed an unimodal size distribution for $H$. niloticus, the nile tilapia $O$. niloticus and C. gariepinus whereas the

Table 13. Trophic categories, relative abundance and commercial importance of the fish caught in the man-made lake of Ahozon, Ouidah city, Southern Benin. J: juvenile; A: adult; HC: highly commercial.

\begin{tabular}{|c|c|c|c|c|}
\hline Feeding category \& Species & $\begin{array}{c}\text { Relative abundance } \\
\text { (\%) }\end{array}$ & $\begin{array}{c}\text { Percent weight } \\
(\%)\end{array}$ & Life history stage & $\begin{array}{l}\text { Fisheries } \\
\text { importance }\end{array}$ \\
\hline Planktinovores/Detritivores & 99.46 & 86.71 & & \\
\hline Sarotherodon galilaeus & 85.31 & 55.45 & $\mathrm{~J} \& \mathrm{~A}$ & $\mathrm{HC}$ \\
\hline Oreochromis niloticus & 2.18 & 1.54 & $\mathrm{~J} \& \mathrm{~A}$ & $\mathrm{HC}$ \\
\hline Tilapia guineensis & 0.75 & 0.33 & $\mathrm{~J} \& \mathrm{~A}$ & $\mathrm{HC}$ \\
\hline Chrysichthys nigrodigitatus & 11.22 & 29.39 & $\mathrm{~J} \& \mathrm{~A}$ & $\mathrm{HC}$ \\
\hline Omnivore & 0.52 & 12.37 & & \\
\hline Heterotis niloticus & 0.52 & 12.37 & $\mathrm{~J} \& \mathrm{~A}$ & $\mathrm{HC}$ \\
\hline Intermediate carnivores & 0.02 & 0.92 & & \\
\hline Clarias gariepinus & 0.02 & 0.92 & A & $\mathrm{HC}$ \\
\hline Total number of individuals: & 6506 & 100 & & \\
\hline
\end{tabular}

Table 14. Trophic categories, relative abundance and commercial importance of the fish caught in the man-made lakes of Bewacodji, Ouidah city, Southern Benin. J: juvenile; A: adult; HC: highly commercial.

\begin{tabular}{|c|c|c|c|c|}
\hline Feeding category \& Species & $\begin{array}{c}\text { Relative } \\
\text { abundance (\%) }\end{array}$ & $\begin{array}{c}\text { Percent weight } \\
(\%)\end{array}$ & Life history stage & $\begin{array}{c}\text { Fisheries } \\
\text { importance }\end{array}$ \\
\hline Planktinovores/Detritivores & 98.59 & 89.83 & & \\
\hline Sarotherodon galilaeus m.* & 91.58 & 62.28 & $\mathrm{~J} \& \mathrm{~A}$ & $\mathrm{HC}$ \\
\hline Tilapia guineensis & 0.04 & 0.04 & $\mathrm{~J} \& \mathrm{~A}$ & $\mathrm{HC}$ \\
\hline Chrysichthys nigrodigitatus & 6.97 & 27.51 & $\mathrm{~J} \& \mathrm{~A}$ & $\mathrm{HC}$ \\
\hline Intermediate carnivores & 1.41 & 10.17 & & \\
\hline Clarias gariepinus & 1.41 & 10.17 & A & $\mathrm{HC}$ \\
\hline Total number of individuals: & 2339 & 100 & & \\
\hline
\end{tabular}

\footnotetext{
${ }^{*} m .=$ multifasciatus
} 
two cichlids, S. galilaeus and T. guineensis exhibited a bimodal size distribution (Figures 2-6).

In the artificial lake of Bewacodji, the SL of fishes ranged from $20 \mathrm{~mm}$ for S. galilaeus to $264 \mathrm{~mm}$ for C. gariepinus and their corresponding weights were $0.20 \mathrm{~g}$ and $217.3 \mathrm{~g}$, respectively. Larger sizes were mostly found in the "open water" habitat whereas smaller sizes were mostly recorded in the "aquatic vegetation". Two (2) larger species, C. gariepinus and C. nigrodigitatus were recorded in the fish community of Lake Bewacodji. Standard length (SL) frequencies histograms established for dominant species exhibited an unimodal size distribution for S. galilaeus, C. nigrodigitatus and C. gariepinus (Figures 7-9).

\subsection{Environmental Correlates}

In both lakes, the total abundance for each fish species collected were plotted against water features to diagnose the relationships between fish attributes and abiotic factors. In lake Ahozon, though not significant, the total

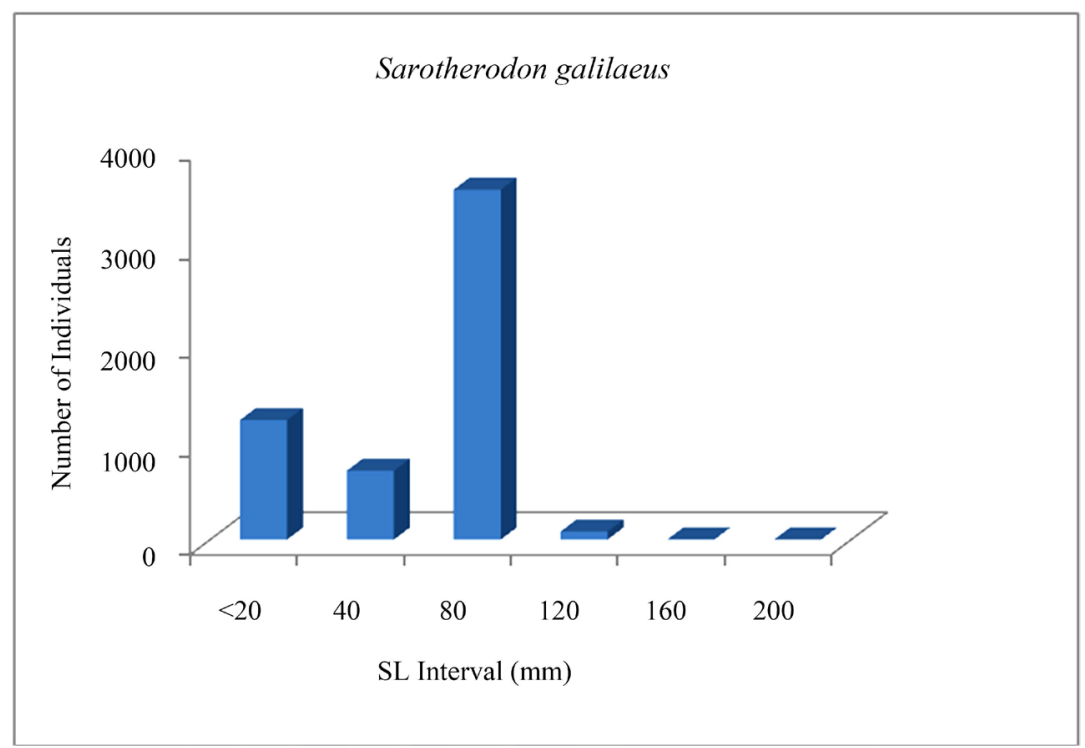

Figure 2. Size structure of Sarotherodon galilaeus $(\mathrm{n}=5550)$ in the man-made lake of Ahozon (South-Benin).

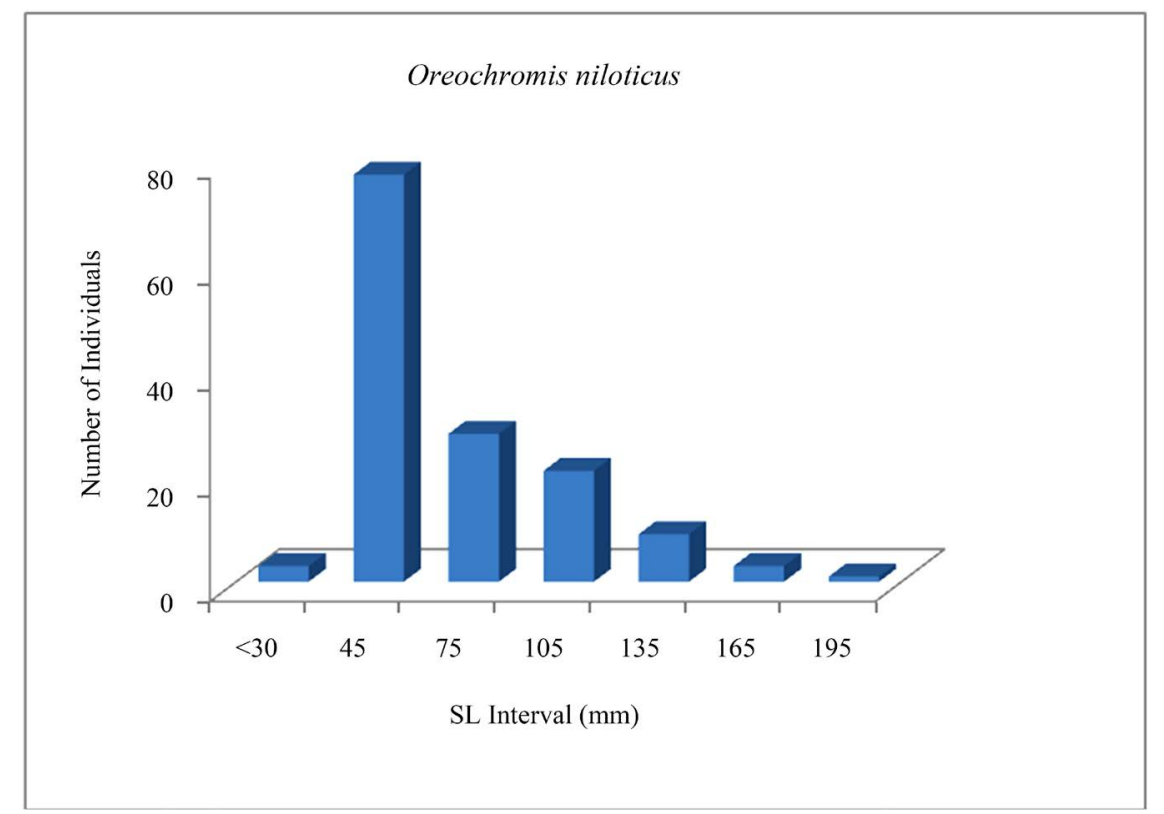

Figure 3. Size structure of Oreochromis niloticus $(\mathrm{n}=142)$ in the man-made lake of Ahozon (South-Benin). 


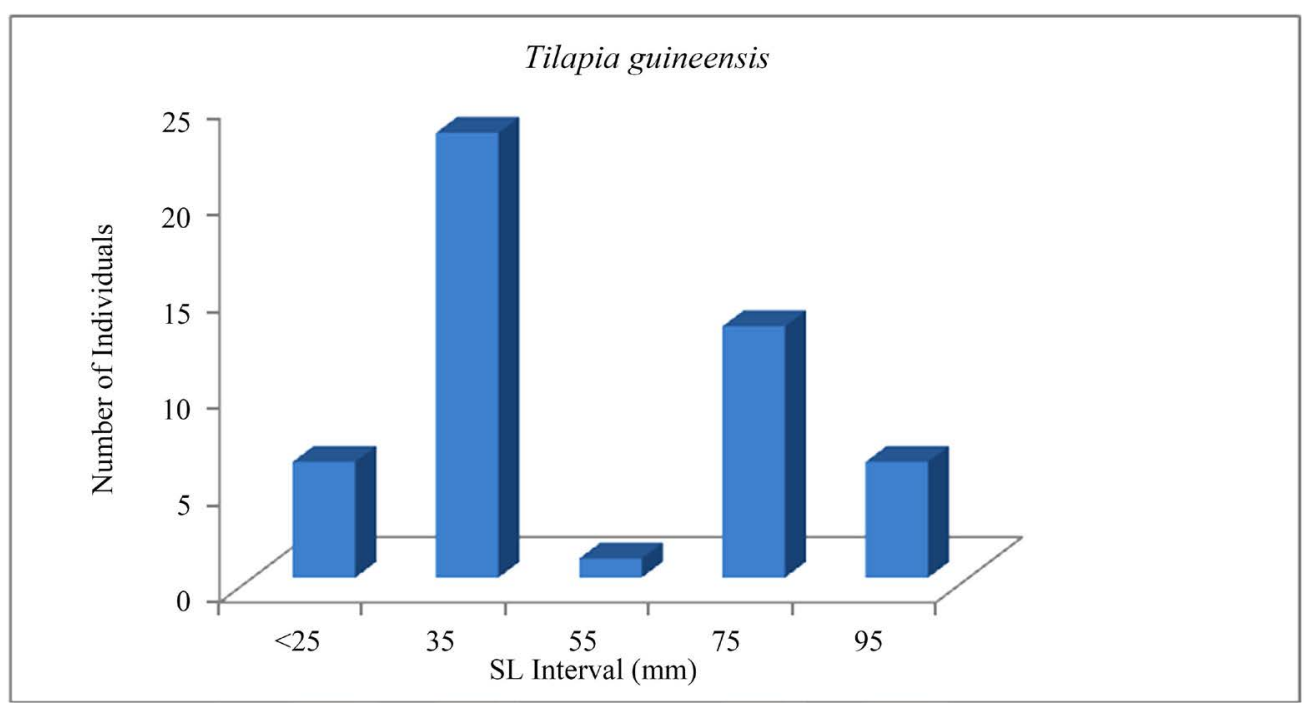

Figure 4. Size structure of Tilapia guineensis $(\mathrm{n}=49)$ in the man-made lake of Ahozon (South-Benin).

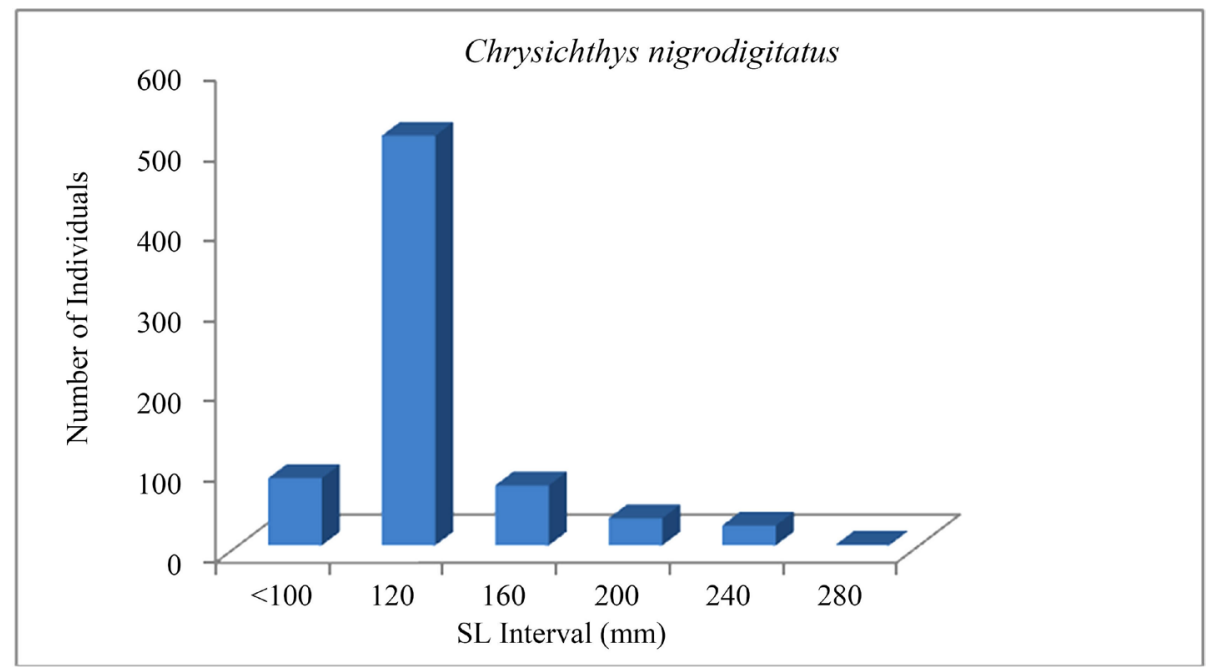

Figure 5. Size structure of Chrysichthys nigrodigitatus $(\mathrm{n}=730)$ in the man-made lake of Ahozon (South-Benin).

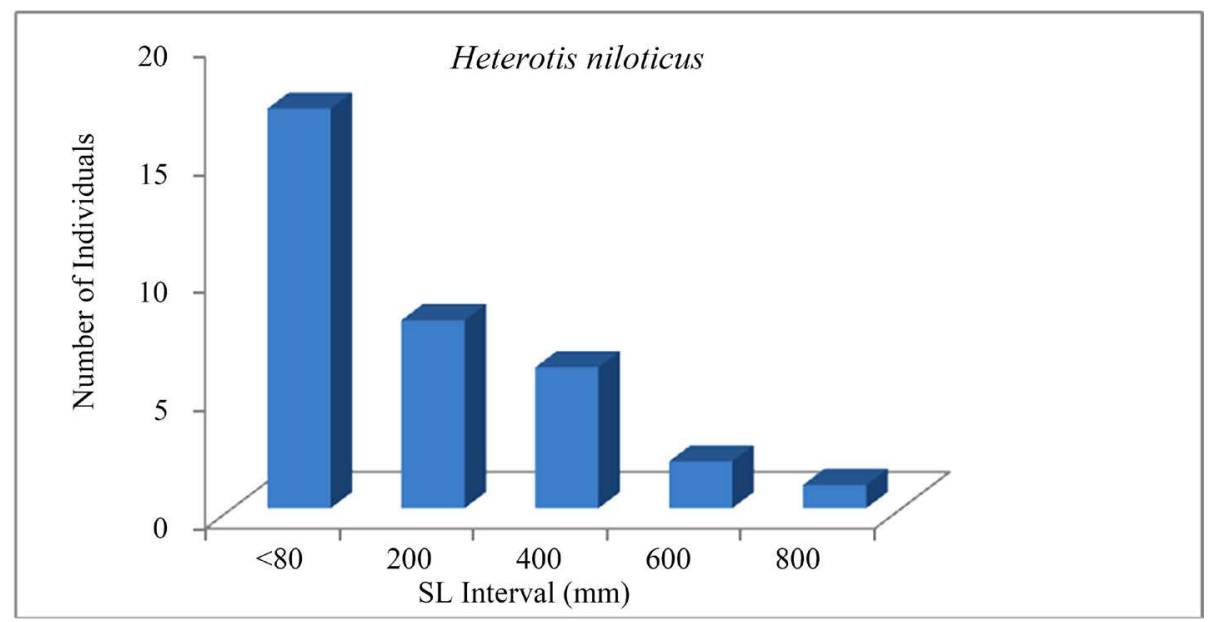

Figure 6. Size structure of Heterotis niloticus $(n=34)$ in the man-made lake of Ahozon (South-Benin). 


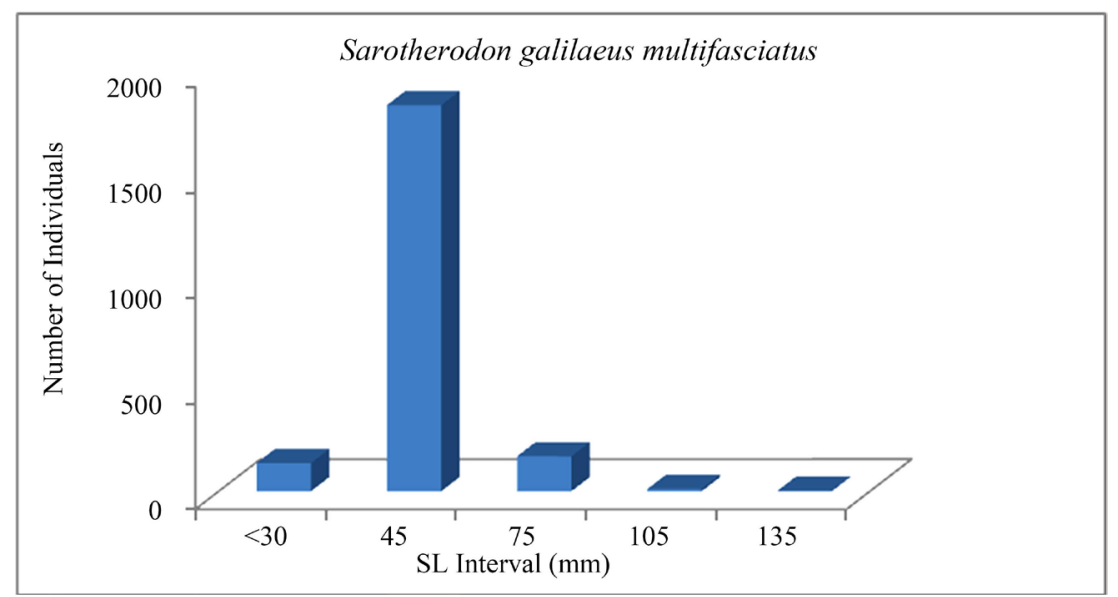

Figure 7. Size structure of Sarotherodon galilaeus multifasciatus $(\mathrm{n}=2142)$ in the man-made lake of Bewacodji (South-Benin).

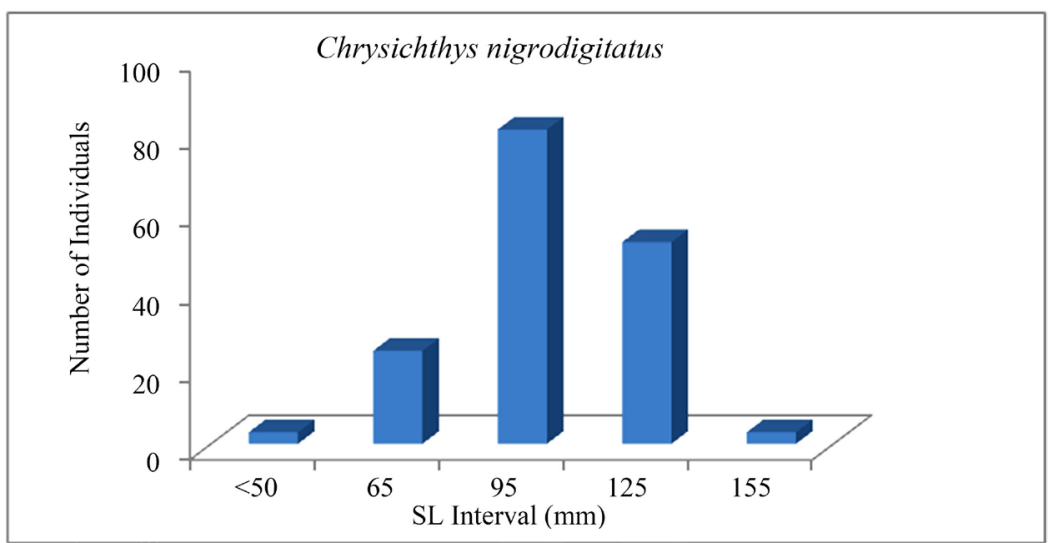

Figure 8. Size structure of Chrysichthys nigrodigitatus $(\mathrm{n}=163)$ in the man-made lake of Bewacodji (South-Benin).

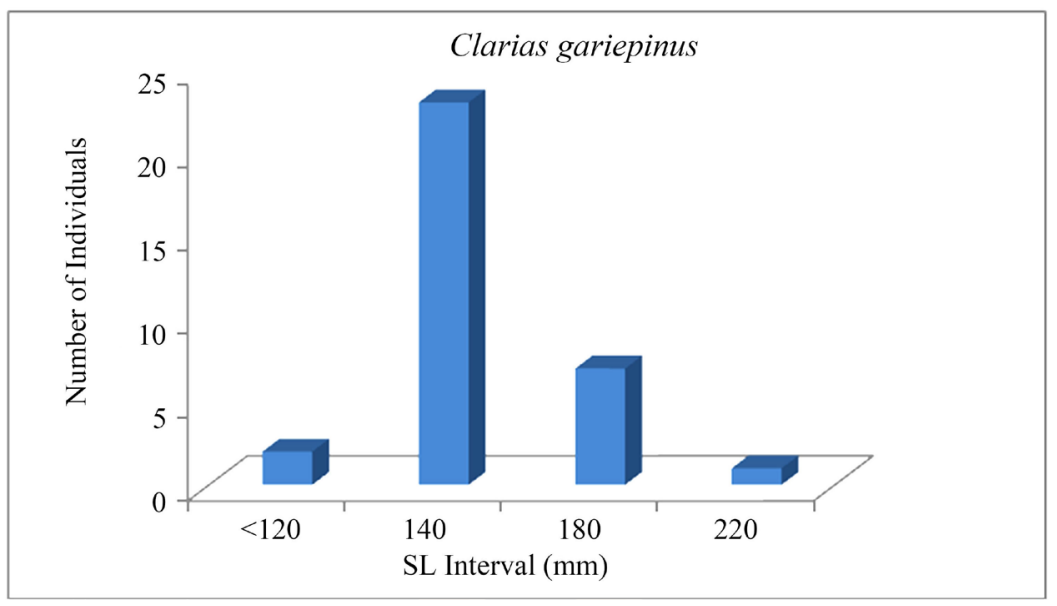

Figure 9. Size structure of Clarias gariepinus $(\mathrm{n}=33)$ in the man-made lake of Bewacodji (South-Benin).

abundance of fish collected was positively correlated with depth $(r=0.59$; regression slope $b=1.59 ; N=20)$, temperature $(r=0.37$; regression slope $b=21.60 ; N=20)$ and conductivity $(r=0.47$; regression slope $b=0.40$; $N=20)$. Though not significant, the abundance of the dominant species, $S$. galilaeus, was positively correlated with depth $(r=0.44 ; b=0.94 ; N=20)$, temperature $(r=0.48 ; b=23.42 ; N=20)$ and conductivity $(r=0.33 ; b=$ $0.295 ; N=20)$. No specific trends were observed in the man-made lake of Bewacodji. 


\subsection{Lake's Resource Exploitation and Degradation Sources}

After the sand-dragging activities, the resulting two man-made lakes, Lake Ahozon and Lake Bewacodji, were abandoned, neglected, and considered as useless or lost lands by the owners. Thus, fisheries and aquacultural management of these man-made lakes by the owners were scant. Nevertheless, sporadic fisheries exploitation implemented by couple of local and migrant fishermen occurred on both lakes. Fishing techniques and gears used were cast nets, traps, gillnets and hooks. On Lake Bewacodji, cast nets were not used because of the dense floating plant covering the lake's surface. Relative to the fish resources, all the species inventoried (6 in Lake Ahozon, 4 in Lake Bewacodji) and dominated by S. galilaeus and C. nigrodigitatus, were of high commercial and economic values.

In addition to fisheries, adjacent wetlands were utilized to grow legumes, salads, carrots, red papers, tomatoes, etc. causing pesticides and fertilizers intrusion and habitat pollution. In particular, Lake Bewacodji undergoes serious environmental degradation such as the daily dumping of huge domestic wastes, source of organic pollution, and the proliferation of floating vegetation mainly, Nymphea, covering the entire lake.

\section{Discussions}

The urgent needs to protect degrading natural aquatic ecosystems, to conserve dwelling fish biodiversity and to feed the growing human population, require a search of alternative environment mediums for a sustainable fish production [21] [26] [39]. In Benin, because of the permanent exploitation of inland sand bed, the resulting man-made has become widespread, but generally unmanaged, neglected, abandoned and considered as lost wetlands. The current ecological study of the man-made lakes assessed water quality and habitat condition, fish assemblages and community structure, utilization of the lakes, degradation impacts and management schemes.

\subsection{Habitat Conditions}

Overall, the water quality of the two man-made lakes studied was significantly different. Indeed, one-way analysis of variance on the water physicochemical traits (transparency, dissolved oxygen concentrations, conductivities, $\mathrm{pH})$ across the two lakes showed significant variations $(P \leq 0.01)$ of the physicochemical parameters between Lake Ahozon and Lake Bewacodji. The calculted $F$-values, along with degrees of freedom and $p$-values were $F_{1,53}=29.765, p=0.0001$ for transparency, $F_{1,53}=9.968, p=0.003$ for dissolved oxygen, $F_{1,53}=8.954, p$ $=0.004$ for conductivity, and $F_{1,53}=35.138, p=0.0001$ for $\mathrm{pH}$. Nevertheless, one-way ANOVA fail to show any significant difference $(P>0.05)$ between the two lakes for depth $\left(F_{1,53}=0.880, p=0.353\right)$ and temperature $\left(F_{1,53}=0.044, p=0.834\right)$.

In general, the water quality of Lake Ahozon was globally favorable not only for a high primary production, but also for the growth and the survival of the fish resources. This favorable environmental quality was indicated by the high water transparencies, the alkaline $\mathrm{pH}$, the high dissolved oxygen and the high conductivity (Table 1). Inversely, the man-made lake of Bewacodji exhibited a weak water quality indicated mainly by an acid $\mathrm{pH}$ (mean: $6.32 \pm 0.58$ ) and low dissolved oxygen concentrations (mean: $3.52 \pm 1.25 \mathrm{mg} / \mathrm{l}$ ). Indeed, during the study, Lake Bewacodji was almost totally covered by a floating plant, Nymphea sp mainly, coupled with the huge daily dumping of domestic waste that caused pollution and degradation of the water quality, critical for an optimal growth and survival of the fish resources. Similar trends of poor water quality were reported for some water bodies such as Lake Hlan, Sô River floodplain, Oueme River floodplain etc. invaded by water hyacinth (Ecchornia crassispes) and showing acid ph (mean: $5.3 \pm 0.20$ ) and low dissolved oxygen ranging between $0.1 \mathrm{mg} / \mathrm{l}$ and 4.8 $\mathrm{mg} / \mathrm{l}[38]$.

Also, when considering a single lake, significant spatial variations in water quality were recorded. In the man-made lake of Ahozon, one-way analysis of variance on the water physicochemical parameters indicated that depth, transparency and dissolved oxygen across the two habitats (open water versus aquatic vegetation) were significantly different $(p \leq 0.05)$. The computed $F$-values, along with degrees of freedom and $p$-values were $F_{1,32}=7.399, p=0.010$ for depth, $F_{1,32}=6.749, p=0.014$ for transparency, $F_{1,32}=11.398, p=0.002$ for dissolved oxygen. Nevertheless, one-way ANOVA fail to show any significant difference $(p>0.05)$ between the open water habitat and aquatic vegetation habitat of the artificial lake of Ahozon for temperature $\left(F_{1,32}=0.016\right.$, $p=0.899)$ for conductivity $\left(F_{1,32}=0.595, p=0.446\right)$ and for $\mathrm{pH}\left(F_{1,32}=0.495, p=0.487\right)$

Inversely, in the man-made lake of Bewacodji, one-way ANOVA on the water physicochemical features fail to show any significant difference $(p>0.05)$ between the open water habitat and aquatic vegetation habitat for 
dissolved oxygen $\left(F_{1,18}=1.826, p=0.193\right)$, temperature $\left(F_{1,18}=0.18, p=0.893\right)$, conductivity $\left(F_{1,18}=0.002, p\right.$ $=0.966)$ and $\mathrm{pH}\left(F_{1,18}=0.144, p=0.709\right)$. This result suggested that in Lake Bewacodji the water quality of the open water and the aquatic vegetation was similar. Indeed, Lake Bewacodji was almost totally covered by a floating plant, mainly Nymphea sp, and hence, the open water habitat and the aquatic vegetation habitat were less distinctive. Nevertheless, one-way analysis of the depth and transparency across the two habitats showed significant differences indicated by $F_{1,18}=9.984, p=0.005$ and $F_{1,18}=6.537, p=0.020$ respectively.

\subsection{Community Structures of the Fish Assemblages}

Both man-made water bodies are freshwater lakes with salinities nearly 0\%. Consequently, only typically freshwater species such as Sarotherodon galilaeus, Sarotherodon galilaeus multifasciatus Heterotis niloticus, and brackish water-tolerant species such as Chrysichthys nigrodigitatus, Clarias gariepinus, Oreochromis niloticus and Tilapia guineensis were encountered in these freshwater habitats [21] [23] [31] [40]. The naturally colonized S. galilaeus, a dominant species in both lakes, probably originated from lagoon Toho-Todougba, a freshwater lake located about $5 \mathrm{~km}$, where this species was also dominant [26]. The natural colonization of $S$. galilaeus, Tilapia guineensis and Clarias gariepinus may originate from the intrusion of fish eggs probably introduced by running waters in these man-made lakes. In contrast, the silver catfish $C$. nigrodigitatus has been introduced by fishermen and though less prominent compared to S. galilaeus, appeared to be well-established. Also, the nile tilapia $O$. niloticus and the African bonytongue, $H$. niloticus has been introduced during the current research to appreciate their establishment, propagation and contribution to species conservation, fisheries and aquaculture valorization.

Both man-made lakes exhibited low species richness, $d=5.89$ in Lake Ahozon, and $d=3.87$ in Lake Bewacodji, with six (6) and four (4) fish species, respectively. Likewise, the Shannon-Weaver index (H') [36] of species diversity were low, $H^{\prime}=0.76$ for Lake Ahozon and $H^{\prime}=0.48$ for Lake Bewacodji. These trends of low species richness and diversity were due to the fact that both lakes were isolated and totally separated from speciose habitats such as rivers, streams, coastal lagoons and marine habitats from which some species could migrate and increase the ichthyofaunal composition of these man-made lakes [41] [42].

In Lake Ahozon, the relatively higher species richness $(\mathrm{d}=5.88)$ and species diversity $\left(\mathrm{H}^{\prime}=0.85\right)$ recorded in the "open water" compared to those of the "aquatic vegetation" habitat $(\mathrm{d}=3.87 ; \mathrm{H}$ ' $=0.33)$, were the result of absence of floating plants in this habitat. The opposite trends were observed in Lake Bewacodji almost totally covered with densely patches floating vegetation (Nymphea sp) with reduced "open water" area that showed low species richness $(\mathrm{d}=2.86)$ and low species diversity $\left(\mathrm{H}^{\prime}=0.28\right)$ compared to the "aquatic vegetation" habitat that exhibited relatively higher species richness $(\mathrm{d}=3.86)$ and species diversity $\left(\mathrm{H}^{\prime}=0.65\right)$. The relatively higher species diversity $\left(\mathrm{H}^{\prime}=0.55\right)$ observed during the dry period was probably due to the concentration of the fish resources in a relatively low volume. The reduced water volume probably increased the likelihood to capture the fish compared to the wet and flood period exhibiting higher water volume. Among fishing gears used to exploit the fish resources, the gill net, a less selective fishing device, showed a higher Shannon-Weaver [36] diversity index. The low evenness, J' $=0.47$ recorded for Lake Ahozon and J' $=0.35$ recorded for Lake Bewacodji indicated unequal representation of the species in the fish assemblages [43]-[45]. Nevertheless, in Lake Ahozon, some higher evenness, J' $=0.84$ and $\mathrm{J}$ ' $=0.98$ were respectively observed for non selective fishing gears such as gillnet and Trap. In the man-made lake of Bewacodji, a higher evenness ( $\mathrm{J}^{\prime}=0.99$ ) were recorded for hooks indicating an equal representation of each species in the fish assemblages.

With regard to species abundance, the freshwater species, S. galilaeus, numerically dominated both habitats and accounted for about $\mathbf{8 5 . 3 1 \%}$ and $91.58 \%$ for Lake Ahozon and Lake Bewacodji, respectively. In addition, $S$. galilaeus dominated the biomass and alone constituted about $55.46 \%$ and $62.26 \%$ of the total biomass of lakes Ahozon and Bewacodji, respectively. This trend is typical for most isolated African freshwater bodies mostly dominated by well-established cichlids species, mainly tilapia, capable of rapid colonization because of their high breeding potential coupled with a degree of trophic plasticity that enable them to adapt and to invade various freshwater ecosystems [46]-[49]. In Benin, Adite and Van Thielen [26] reported similar trends for Lagoon Toho-Todougba dominated by S. galilaeus making 73\% of the total catches. Also, Lake Toho, a flooding lake of the Mono River (South-Benin), was dominated by Sarotherodon melanotheron accounting for about $68.46 \%$ of the total sample [50]. The relatively high biomass of the introduced claroteid, C. nigrodigitatus (29.40\% in Lake Ahozon, 27.51\% in Lake Bewacodji) indicated a substantial contribution of this species to the fish production in both lakes, and hence, indicated a relatively good establishment of this catfish. In Lake Ahozon, the African 
bonytongue $H$. niloticus, although newly introduced, contributed substantially to the fish production with a percent biomass of $12.37 \%$. Currently, the three remaining species C. gariepinus, T. guineensis and O. niloticus were trivial and require continued follow-up to evaluate their establishment.

Though not significant, the positive correlations $(0.33 \leq r \leq 0.59)$ between the physicochemical factors and the abundance of the fish assemblages and that of the dominant species, S. galilaeus indicated that the increase in the fish abundance of Lake Ahozon was controlled by depth, temperature and conductivity. No specific trends were observed in the polluted man-made lake of Bewacodji showing a water surface almost totally covered by densely patched floating plants.

In term of trophic structure, the fish community of both lakes was dominated by planktonovores/detritivores species, mainly S. galilaeus, O. niloticus (introduced only in Lake Ahozon), T. guineensis and C. nigrodigitatus making numerically 99.46\% in Lake Ahozon and 98.59\% in Lake Bewacodji. During this study, the introduction of $H$. niloticus, an omnivore and O. niloticus, a planktinovore/detritivore is an advantage because their establishment will allow to appropriately and efficiently exploit the foods resources in order to increase the fish yield and production. The introduction of intermediate carnivores and top carnivores should be under control to avoid high predation on larvae and juveniles.

Though perfectly established in Lake Ahozon, the dominant species, S. galilaeus, showed moderate mean size (56.57 $\pm 28.41 \mathrm{~mm}-\mathrm{SL}$ ). The early maturation and the continuous reproduction strategy (adults spawn all seasons) shown by most cichlids, especially, the group of tilapia, coupled with the low abundance of predator ( $C$. gariepinus: $0.02 \%$ in Lake Ahozon; $1.41 \%$ in Lake Bewacodji) could have increased the abundance of S. galilaeus juveniles and sub adults accounting together for about $98 \%$ of Lake Ahozon sub population. Probably, this water body may have been overloaded and the lake's caring capacity may have been compromised, causing decrease in fish growth rate. Nevertheless, the maximum size recorded reached $192 \mathrm{~mm}$-SL. Inversely, the detritivore C. nigrodigitatus (mean size: $127.10 \mathrm{~mm}-\mathrm{SL}$ in Ahozon; $100.90 \mathrm{~mm}-\mathrm{SL}$ in Bewacodji), the omnivore $H$. niloticus (mean size: $332.24 \mathrm{~mm}$-SL in Ahozon) and the intermediate carnivore C. gariepinus (mean size: 506 mm-SL in Ahozon; 153.48 mm-SL in Bewacodji) exhibited relatively high size, probably because of their relatively large ecological niche compared to S. galilaeus, a specialist planktonovore [3] [51].

In the man-made lake of Ahozon, degradation sources were reduced and limited to sporadic agriculture using pesticides and fertilizers, and hence, should not be a major threat for the water body. The lake's users should be sensitized to practice ecological sound agriculture without pesticides and fertilizers and using only compost. In the artificial lake of Bewacodji, in addition to the utilization of pesticides and fertilizers for agriculture purpose, two other major threats were 1) the daily dumping of huge domestic wastes in the lake, causing organic pollution and 2) the proliferation of floating vegetation (Nymphea sp), covering the lake and negatively modifying the water quality by reducing the dissolved oxygen, the $\mathrm{pH}$ and the primary production, and hence, negatively affected the fish community structure. Furthermore, these floating plants impeded navigation and access to the lake. The same trends of floating vegetation (Ecchornia crassipes, Pistia stratiostes, Nymphea sp) proliferation have been reported for many freshwater lakes (Toho, Cele, Azili, Hlan etc.) and rivers (Oueme, Sô, Mono, Couffo, Okpara, Niger, etc.) in Benin, and has become a major degradation source for the whole aquatic ecosystem and a major threat for the biological diversity [15].

\subsection{Species Conservation and Fisheries Management Implications}

The current ecological study on the man-made lakes of Ahozon and Bewacodji provide valuable information and database on habitat conditions, fish composition, richness, abundance, diversity, spatial and seasonal distributional patterns of the fishes. Also, disturbances and degradation issues were evaluated. The water quality of Lake Ahozon indicated that this habitat is favorable for a high primary production and guaranties a relatively high growth and survival of the fish resources. A holistic and sustainable management scheme to be implemented should include:

1) Aquacultural valorization: this valorization should emphasis on the introduction of target and highly economic and commercial species that could utilize the unexploited ecological niche of the lakes. In this study, in addition to the detritivore $C$. nigrodigitatus introduced by the fishermen, the African bonytongue, $H$. niloticus, an omnivore and the nile cichlid, $O$. niloticus, a planktinovore has been introduced to increase the fish yield and production. Heterotis is among the most valuable fish species and a single adult bonytongue cost nearly $\$ 25$. A follow-up will permit to evaluate their establishment in the future. Also, a fish culture technique, such as the "floating cage" could be installed on the artificial lake as medium environment to raise fish. Likewise, predator 
species such as Parachanna obscura should be introduced to regulate tilapia species population.

2) Ecological sound agriculture: The adjacent wetlands of the lakes could be utilized to grow legumes, salads, carrots, red papers, tomatoes, etc. but, without the utilization of pesticides and fertilizers capable of causing pollution.

3) Ecological sound ecotourism: This ecotourism may include aquarium, sport fisheries, aesthetical creations, and navigation.

4) Education and training program: This requires collaboration with agriculture school and especially, those involved in fish culture, fisheries and biodiversity conservation.

5) Scientific research: The man-made lakes could be used for scientific research by the University laboratory as the lakes harbor a huge aquatic biological diversity, from micro vegetation to superior animals.

6) Habitat protection and species conservation program: This program may include the protection of the lake fringes by planting grass and trees and biodiversity conservation.

7) Environment monitoring program: This monitoring should be implemented as follow-up to periodically assess the ecological status of the lakes. The monitoring could emphasize mainly on the periodic evaluation of habitat conditions, the hydrology and the living aquatic resources.

8) Particularly, in Lake Bewacodji, the grassroots and the lake users should be sensitized to stop with dumping of domestic wastes in this lake. Also, floating vegetation (Nymphea sp), should be taken out to restore the water quality and the fish community structure.

\section{Conclusion}

This investigation gives valuable information on the ecology and the fish community structure of two man-made lakes, Lake Ahozon and Lake Bewacodji of Southern Benin. Overall, the environmental conditions of Lake Ahozon were globally favorable for the primary production, the growth and the survival of the dwelling fish resources. Inversely, the man-made lake of Bewacodji exhibited a poor water quality because of the acid $\mathrm{pH}$ and the low dissolved oxygen concentrations caused by the floating plants and the dumping of domestic wastes. In general, species richness and species diversity indices were low. However, the two fish communities were consistently dominated by a tilapine cichlid, Sarotherodon galilaeus which constituted an important economically and commercially fish resources in these two habitats. A sustainable and successful exploitation of both lakes requires an integrated and holistic management scheme including habitat protection and species conservation, aquacultural valorization, ecological sound agriculture, ecological sound ecotourism, education and training, scientific research and environment monitoring. Also, this research should be extended to numerous man-made lakes in Benin to explore potentials for fisheries, aquaculture and biodiversity conservation.

\section{Acknowledgements}

Financial assistance and logistic were provided by the "Laboratoire d'Ecologie et de Management des Ecosystèmes Aquatiques, Département de Zoologie, Faculté des Sciences et techniques, Université d'AbomeyCalavi”. We express our gratitude to Mr Doukpo Célestin, the owner of the artificial lakes to allow us to conduct this investigation on both man-made lakes. We are also grateful to Mr Houessinon M. Geoffroy, Houndjetin Louis and Djihouessi Bernold for their assistance in fish sampling and laboratory works. We thank the numerous reviewers for their thorough peer-review of this manuscript.

\section{References}

[1] Welcomme, R.L. (1979) Fisheries Ecology of Floodplain Rivers. Longman, New York.

[2] Lowe-McConnell, R.H. (1987) Ecological Studies in Tropical Fish Communities. Cambridge University Press, Cambridge. http://dx.doi.org/10.1017/CBO9780511721892

[3] Adite, A. and Winemiller, K.O. (1997) Trophic Ecology and Ecomorphology of Fish Assemblages in Coastal Lakes of Benin, West Africa. Ecoscience, 4, 6-23.

[4] Lalèyè, P., Niyonkuru, C., Moreau, J. and Teugels, G.G. (2003) Spatial and Seasonal Distribution of the Ichthyofauna of Lake Nokoué, Benin, West Africa. African Journal of Aquatic Sciences, 28, 151-161. http://dx.doi.org/10.2989/16085910309503779

[5] Adite, A., Winemiller, K.O. and Fiogbé, E.D. (2006) Population Structure and Reproduction of the African Bonytongue Heterotis niloticus in the Sô River-Floodplain System (West Africa): Implications for Management. Ecology of 
Freshwater Fish, 15, 30-39. http://dx.doi.org/10.1111/j.1600-0633.2005.00119.x

[6] Mustapha, M.K. (2010) Heterotis niloticus (Cuvier, 1829), a Threatened Fish Species in Oyun Reservoir, Offa, Nigeria: The Need for Its Conservation. Asian Journal of Experimental Biological Sciences, 1, 1-7.

[7] Smith, R.L. (1992) Elements of Ecology. 3rd Edition, HarperCollins Publishers Inc., New York.

[8] Fagnon, M.S., Chikou, A., Youssao, I. and Laleye, P. (2013) Caractérisation morphologique des populations de Sarotherodon melanotheron (Pisces, Cichlidae) en eaux douces et saumâtres au Sud Bénin. International Journal of Biological and Chemical Sciences, 7, 619-630. http://dx.doi.org/10.4314/ijbcs.v7i2.18

[9] Hurtado, L.A., Carrera, E., Adite, A. and Winemiller, K.O. (2013) Genetic Differentiation of a Primitive Teleost, the African Bonytongue Heterotis niloticus, among River Basins and within a Floodplain River System in Benin, West Africa. Journal of Fish Biology, 83, 682-690. http://dx.doi.org/10.1111/jfb.12198

[10] Lopez-Fernandez, H., Winemiller, K.O., Adite, A., Arrington, D.A. and Layman, C.A. (2003) Freshwater Fish Diversity in Benin, West Africa, and Challenge for Its Conservation. Proceedings University of Abomey-Calavi Conférence, African Fish and Fisheries, Cotonou, 85-86.

[11] Lawson, E.O. (2010) Morphometric Measurements and Meristic Counts in Mudskipper (Periophthalmus papilio) from Mangrove Swamps of Lagos lagoon, Nigeria. Journal of Applied Biosciences, 34, 2166-2172.

[12] Adite, A., Toko, I.I. and Gbankoto, A. (2003) Fish Assemblages in the Degraded Mangrove Ecosystems of the Coastal Zone, Benin, West Africa: Implications for Ecosystem Restoration and Resources Conservation. Journal of Environmental Protection, 4, 1461-1475. http://dx.doi.org/10.4236/jep.2013.412168

[13] Welcomme, R.L. (1971) A Description of Certain Indigenous Fishing Methods from Southern Dahomey. African Journal of Tropical Hydrobiology and Fisheries, 1, 129-140.

[14] Louis, M., Bouchon, C. and Bouchon-Navaro, Y. (1995) Spatial and Temporal Variations of Mangrove Fish Assemblages in Martinique (French West Indies). Hydrobiologia, 295, 275-284. http://dx.doi.org/10.1007/BF00029134

[15] Adite, A., Abou, Y., Sossoukpe, E., Gbaguidi, G. and Fiogbe, E.D. (2013) Meristic and Morphological Characterization of the Freshwater Prawn, Macrobrachium macrobrachion (Herklots, 1851) from the Mono River-Coastal Lagoom System, Southern Benin (West Africa): Implications for Species Conservation. International Journal of Biodiversity and Conservation, 5, 704-714.

[16] Pliya, J. (1980) La pêche dans le Sud-ouest du Bénin: étude de géographie appliquée sur la pêche continentale et maritime. Agence de Coopération culturelle et technique, Paris.

[17] Gbaguidi, G.A.M.H. (2012) Caractérisation morphométrique et écologie trophique de deux espèces de crevettes d'eaux douces Macrobrachium macrobrachion (Herklots, 1851) et Macrobrachium vollenhovenii (Herklots, 1857) du système fluvio-lagunaire Mono-Lagune Côtière (Sud-Bénin). Master’s Thesis, Université d’Abomey-Calavi, Abomey Calavi.

[18] Okpeicha, S.O. (2011) Biodiversité et exploitation des poissons du barrage de la SUCOBE dans la commune de Savè au Bénin. Master’s Thesis, Faculté des Sciences Techniques/UAC, Abomey-Calavi.

[19] Micha, J.C. (1973) Etude des populations piscicoles de l’Ouganda et tentation de sélection et d'adaptation de quelques espèces à l'étang de pisciculture. Centre Technique Forestier Tropicale, Nogent-sur-Marne,110 p.

[20] Moreau, J. (1982) Exposé synoptique des données biologiques sur Heterotis niloticus (Cuvier, 1929). Food and Agriculture Organization Synopsis de pêches, 131, 1-45.

[21] Levêque, C., Paugy, D. and Teugels, G.G. (1990) The Fresh and Brackish Water Fishes of West Africa. Tome 1, Editions ORSTOM/MRAC, Paris.

[22] Reed, W., Burchard, J., Hopson, A.J., Jenness, J. and Yaro, I. (1967) Fish and Fisheries of Northern Nigeria. Ministry of Agriculture Northern Nigeria.

[23] Leveque, C. (1997) Biodiversity Dynamics and Conservation: The Freshwater Fish of Tropical Africa. Cambridge University Press, Cambridge.

[24] GCLME (2006) Guinea Current Large Marine Ecosystem Report. GEF/UNIDO/UNDP/UNEP/ US-NOAA. http://Projects.csg.uwaterloo.ca/inweh/content/1188

[25] Capo-Chichi, Y.J. (2006) Monographie de la commune de Grand-popo. Cabinet “Afrique Conseil”, 46 p.

[26] Adite, A. and Van Thielen, R. (1995) Ecology and Fish Catches in Natural Lakes of Benin, West Africa. Environmental Biology of Fishes, 43, 381-391. http://dx.doi.org/10.1007/BF00001173

[27] Akoegninou, A., Oyede, L.M. and Toffi, M. (1993) La mangrove du Benin: Environnement physique, végétation, et essais de gestion. Technical Report, Faculté des Sciences et Techniques, Université d'Abomey-calavi, Benin.

[28] Djihouessi, B.M. (2015) Ecologie et valorization piscicole des lacs artificiels du Sud-Bénin (Bénin, Afrique du de l'Eouest). Master's Thesis, FAST/UAC, Abomey-Calavi. 
[29] Needham, G.J. and Needham, P.R. (1962) A Guide to the Study of Freshwater Biology. Holden-Day, Inc., San Francisco.

[30] Winemiller, K.O. (1992) Fish Assemblages across a Complex, Tropical Freshwater/Marine Ecotone. Environmental Biology of Fishes, 3, 29-50. http://dx.doi.org/10.1007/BF00004783

[31] Levêque, C., Paugy, D. and Teugels, G.G. (1990) The Fresh and Brackish Water Fishes of West Africa. Tome 2, Editions ORSTOM/MRAC, Paris.

[32] Van Thielen, R., Hounkpe, C., Agon, G. and Dagba, L. (1987) Guide de détermination des Poissons et Crustacés des Lagunes et Lacs du Bas-Bénin. Direction des Pêches, Cotonou.

[33] McConnell, R.H.L. (1975) Fish Communities in Tropical Freshwaters. Longman, London.

[34] Morgan, G.A., Grieggo, O.V. and Gloekner, G.W. (2001) SPSS for Windows: An Introduction to Use and Interpretation in Research. Lawrence Erlbaum Associates, Publishers, Mahwah.

[35] Margalef, R. (1968) Perspective in Ecological Theory. University of Chicago Press, Chicago.

[36] Shannon, C. and Weaver, E. (1963) The Mathematical Theory of Communication. University of Illinois Press, Urbana.

[37] Halliday, I.A. and Young, W.R. (1996) Density, Biomass and Species Composition of Fish in a Subtropical Rhizophora stylosa Mangrove Forest. Marine and Freshwater Research, 47, 609-615. http://dx.doi.org/10.1071/MF9960609

[38] Adité, A., Winemiller, K.O. and Fiogbe, E.D. (2005) Ontogenetic, Seasonal; and Spatial Variation in the Diet of Heterotis niloticus (Osteoglossiformes: Osteoglossidae) in the Sô River and Lake Hlan, Benin, West Africa. Environmental Biology of Fishes, 73, 367-378. http://dx.doi.org/10.1007/s10641-004-5563-9

[39] Moyle, P.B. and Cech, J.J. (1988) Fish: An Introduction to Ichthyology. 2nd Edition, Prentice-Hall, Inc., Englewood Cliffs.

[40] Skelton, P.H. (1993) A Complete Guide to the Freshwater Fishes of Southern Africa. Southern Book Publishers, Birmingham.

[41] Gbaguidi, A.S. and Pfeifer, V. (1988) Statistiques des pêches continentales; année 1987. Services Etudes et Statistiques. Projet Pêche Lagunaire, Deutshe Gesellschaft Fur Technische Zusammenarbeit (GTZ) GMBH et Direction des Pêches-Cotonou, Bénin.

[42] Murphy, B.R. and Willis, D.W. (1996) Fisheries Techniques. 2nd Edition, American Fisheries Society, Bethesda.

[43] Krebs, C.J. (1989) Ecological Methodology. Harper \& Row Publishers, New York.

[44] Morton, R.M. (1990) Community Structure, Density, and Standing Crop of Fishes in a Subtropical Australian Mangrove Area. Marine Biology, 105, 385-394. http://dx.doi.org/10.1007/BF01316309

[45] Williamson, I. and King Mather, C.B. (1994) A Comparison of Fish Communities in Unmodified and Modified Inshore Habitats of Raby Bay, Queensland. Estuarine, Coastal and Shelf Sciences, 39, 401-411. http://dx.doi.org/10.1006/ecss.1994.1072

[46] Fryer, G. and Iles, T.D. (1972) The Cichlid Fishes of the Great Lakes of Africa: Their Biology and Evolution. Oliver \& Boyd, Edinburgh.

[47] Snoeks, J. (2000) How Well Known Is the Ichyodiversity of the Large East African Lakes? Advances in Ecological Research, 31, 17-38. http://dx.doi.org/10.1016/S0065-2504(00)31005-4

[48] Mbega, J.D. (2004) Biodiversité des poisons du bassin inférieur de l’Ogooué (Gabon). Thèse de docteur en sciences, Facultés Universitaires Notre dame de la paix, Namur.

[49] Adepo-Gourène, B. and Gourène, G. (2008) Différenciation morphologique des populations naturelles d'une sousespèce de Tilapia Sarotherodon melanotheron melanotheron Rüppell, 1852 (Teleostei; Cichlidae) de côte d'Ivoire. Science \& Nature, 5, 15-27. http://dx.doi.org/10.4314/scinat.v5i1.42148

[50] Tossavi, E.C. (2011) Evolution de la biodiversité et de l'exploitation des poissons du lac Toho (Sud-Benin): Implication pour la gestion durable des ressources halieutiques. Master's Thesis, Faculté des Sciences et Techniques, Université d’Abomey-Calavi, Abomey Calavi.

[51] Bowen, S.H. and Allanson, B.R. (1982) Behavioral and Trophic Plasticity of Juvenile Tilapia mossambica in Utilization of the Unstable Littoral Habitat. Environmental Biology of Fishes, 7, 357-362.

http://dx.doi.org/10.1007/BF00005570 